\title{
THE IMMUNOLOGY OF SUSCEPTIBILITY AND RESISTANCE TO LEISHMANIA MAJOR IN MICE
}

\author{
David Sacks* and Nancy Noben-Trauth \\ Established models of T-helper-2-cell dominance in BALB/c mice infected with Leishmania major \\ - involving the early production of interleukin-4 by a small subset of Leishmania-specific CD4 ${ }^{+}$ \\ T cells - have been refined by accumulating evidence that this response is not sufficient and, \\ under some circumstances, not required to promote susceptibility. In addition, more recent \\ studies in L. major-resistant mice have revealed complexities in the mechanisms responsible for \\ acquired immunity, which necessitate the redesign of vaccines against Leishmania and other \\ pathogens that require sustained cell-mediated immune responses.
}

THELPER $1 /$ T HELPER 2 $\left(\mathrm{T}_{\mathrm{H}} 1 / \mathrm{T}_{\mathrm{H}}\right)$. A classification of $\mathrm{CD} 4^{+} \mathrm{T}$ cells on the basis of the patterns of cytokines that they secrete. $T_{H} 1$ cells secrete large amounts of IFN- $\gamma$ and associated pro-inflammatory cytokines. $\mathrm{T}_{\mathrm{H}} 2$ cells secrete large amounts of IL-4 and associated cytokines that promote antibody production by B cells. $T_{H} 1 / T_{H} 2$ cytokines can cross-regulate each other's responses. An imbalance of $\mathrm{T}_{\mathrm{H}} 1 / \mathrm{T}_{\mathrm{H}} 2$ responses is thought to contribute to the pathogenesis of various infections, allergic responses and autoimmune diseases.

${ }^{*}$ Laboratory of Parasitic Diseases, National Institute of Allergy and Infectious Diseases, National Institutes of Health, Bethesda, Maryland 20892, USA. ${ }^{\ddagger}$ Department of Immunology, George Washington University, 2300 Eye Street, Washington, DC 20037, USA. Correspondence to D.S. e-mail:dsacks@nih.gov doi:10.1038/nri933
The first direct demonstration of the relevance of the T HELPER 1/T HELPER $2\left(\mathrm{~T}_{\mathrm{H}} 1 / \mathrm{T}_{\mathrm{H}} 2\right)$ balance to the regulation of disease outcome in vivo arose from studies in the Leishmania major mouse model (see TIMELINE). Natural transmission of cutaneous leishmaniasis caused by L. major infection is by the sandfly vector Phlebotomus papatasi, which inoculates a small number $(100-1,000)$ of infectious-stage metacyclic promastigotes into the skin (FIG. 1). L. major is distributed widely through northern Africa, the Middle East and central Asia. Infection of natural rodent reservoirs and of human hosts leads invariably to the development of localized cutaneous lesions that eventually heal, and to the generation of life-long immunity to re-infection. In the laboratory, most mouse genotypes control L. major infection also, which is initiated typically by needle inoculation of a large number $\left(10^{4}-10^{7}\right)$ of parasites into subcutaneous sites, such as the footpad or base of the tail (BOX 1). However, certain strains - such as BALB/c mice - fail to control infection and develop progressive lesions and systemic disease. These mice are thought to be a model of non-healing forms of the human disease — such as kala-azar or diffuse cutaneous leishmaniasis - that are associated with infection by other species of Leishmania (for the genetics of L. major infection, see FIG. 2 ).

The genetic predisposition for susceptibility or resistance to $L$. major infection in mice correlates with the dominance of an interleukin-4 (IL-4)-driven $\mathrm{T}_{\mathrm{H}} 2$ response that causes disease or an IL-12-driven, interferon- $\gamma($ IFN- $\gamma)$-dominated $\mathrm{T}_{\mathrm{H}} 1$ response that promotes healing and parasite clearance, respectively (for a model of $\mathrm{T}_{\mathrm{H}} 1 / \mathrm{T}_{\mathrm{H}} 2$ development, see FIG. 3). Recent data, however, have challenged the simplicity of this model and have revealed further complexities in cytokine regulation and the mechanisms of acquired resistance and immune escape. In this review, we consider recent findings in the L. major mouse model in the context of earlier studies, and attempt to reconcile apparent differences and emphasize those aspects of the $\mathrm{T}_{\mathrm{H}} 1 / \mathrm{T}_{\mathrm{H}} 2$ model that have been altered or refined.

\section{$T_{\mathrm{H}}$ 2-cell development and susceptibility}

$T_{H} 2$-cell development in BALB/c mice. The apparent resolution of infection with $L$. major in BALB/c mice treated at the time of infection with an anti-IL-4 monoclonal antibody ${ }^{1,2}$ or in IL-4-deficient BALB/c mice ${ }^{3,4}$ helped to establish the view that early production of IL- 4 drives the polarized $\mathrm{T}_{\mathrm{H}} 2$ response that is responsible for suppressing $\mathrm{T}_{\mathrm{H}} 1$-cell development and inhibiting the high-level secretion of IFN- $\gamma$ that is required to activate infected macrophages for parasite killing. There is also convincing evidence that the early IL-4 response is confined largely to an oligoclonal population of $\mathrm{CD} 4^{+} \mathrm{T}$ cells with a $\mathrm{V} \beta 4 \mathrm{~V} \alpha 8 \mathrm{~T}$-cell receptor (TCR) that recognize the 
Timeline | The Leishmania major mouse model

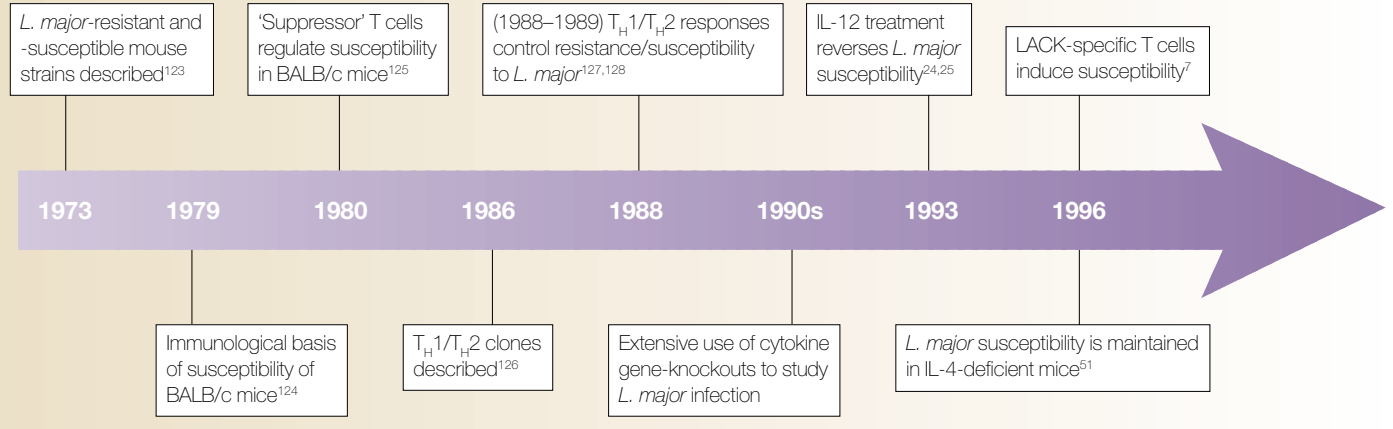

IL, interleukin; LACK, Leishmania homologue of receptors for activated C kinase; $T_{H} 1, T$ helper 1.
IL-4 REPORTER MICE

Genetically engineered knock-in mice in which the gene encoding IL- 4 has been replaced by sequences that encode a reporter molecule, such as green fluorescent protein (GFP). When the IL-4 promoter region is activated, GFP is expressed and living cells can be visualized by flow cytometry.

MHC CLASS II TETRAMERS A method of visualizing antigenspecific $\mathrm{CD} 4^{+} \mathrm{T}$ cells by flow cytometry. Typically, four MHC class II molecules with their associated peptides are held together by streptavidin, which has four binding sites for biotin which is attached to the tail of the MHC molecule. These four peptide-MHC complexes (tetramers) can bind peptidespecific T-cell receptors. The streptavidin molecules are often labelled with a fluorochrome so that binding can be assessed by flow cytometry. Similarly, MHC class I tetramers can be engineered to track $\mathrm{CD} 8^{+} \mathrm{T}$-cell receptors.

SEVERE COMBINED IMMUNODEFICIENCY (SCID). Mice of this phenotype lack functional $\mathrm{T}$ and $\mathrm{B}$ cells owing to a spontaneous mutation in the Prkdcgene (protein kinase, DNA activated, catalytic polypeptide) located on chromosome 16. These mice are often used for the reconstitution of T-cell subsets to study their functions in vivo.
Leishmania antigen LACK (Leishmania homologue of receptors for activated $\mathrm{C}$ kinase $)^{5}$. This conclusion is based on the observation that infected $V \beta 4$-deficient $B A L B / c$ mice mount stronger $T_{H} 1$ responses than wildtype $\mathrm{BALB} / \mathrm{c}$ mice and control their lesions ${ }^{6}$, as do $\mathrm{BALB} / \mathrm{c}$ mice that are tolerant of LACK as a result of the transgenic expression of the protein ${ }^{7}$. It has been proposed that LACK-specific $\mathrm{V} \beta 4 \mathrm{~V} \alpha 8 \mathrm{CD} 4^{+} \mathrm{T}$ cells form a unique lineage in $\mathrm{BALB} / \mathrm{c}$ mice that is biased to produce IL-4, because their TCRs have relatively low affinity for peptide-MHC ${ }^{8}$. So, to the extent that inherent differences in the T-cell compartment control resistance or susceptibility to $L$. major ${ }^{9}$, a model has emerged in which the susceptibility of BALB/c mice is determined by a relatively high frequency of LACK-reactive cells that are biased to produce IL-4 after early exposure to $L$. major.

Importance of the early $T_{H} 2$ response. The importance of early IL-4 production by LACK-reactive $\mathrm{CD} 4^{+} \mathrm{T}$ cells as the determining variable in susceptibility to $L$. major infection is not, however, consistent with several findings. In earlier studies, $\mathrm{V} \beta 4 \mathrm{~V} \alpha 8 \mathrm{TCR}$ usage was found to be similar in L. major-infected BALB/c and C57BL/6 mice $^{10}$, and LACK-specific T cells were found to produce a burst of IL-4 in resistant B10.D2 mice ${ }^{11}$. Most recently, in studies in IL-4 REPORTER MICE - which contain a knock-in gene encoding IL-4 linked to enhanced green fluorescent protein (GFP) - the frequency and kinetics of IL-4-producing cells induced by L. major that bind a LACK-MHC CLASS II TETRAMER were found to be similar in resistant and susceptible strains ${ }^{12}$. Indeed, early, albeit transient, IL-4 responses after L. major infection in resistant mouse strains have been a fairly consistent finding ${ }^{13-17}$ (FIG. 4). Furthermore, although injections of IL-4 (REF. 2) or anti-IL-12 antibodies ${ }^{18}$ at the time of parasite challenge promote a strong $\mathrm{T}_{\mathrm{H}} 2$ response in $\mathrm{C} 3 \mathrm{H}$ mice, the response is transient and does not reverse the normal resistant phenotype of these mice in the long term. Taken together, these data indicate that the ability to redirect an early $\mathrm{T}_{H} 2$ response is the more probable determinant of resistance in the mouse model.

The necessity to ablate $\mathrm{T}_{\mathrm{H}} 2$ cytokine production to effect a cure has been shown using transgenic resistantbackground mice with constitutive expression of either IL-4 (REFS 19,20) or IL-10 (REF. 21). In each case, the mice failed to control L. major infection despite generating a relatively strong $\mathrm{T}_{\mathrm{H}} 1$ response. Even from the strong $\mathrm{T}_{\mathrm{H}}$ 2-polarizing environment of $L$. major-infected $\mathrm{BALB} / \mathrm{c}$ mice, an effector $\mathrm{CD} 4{ }^{+} \mathrm{CD} 45 \mathrm{RB}^{\text {hi }} \mathrm{T}$-cell subset could be recovered that could transfer immunity to SEVERE COMBINED IMMUNODEFICIENT (SCID) mice $^{22}$. So, the sustained production of $\mathrm{T}_{\mathrm{H}} 2$ cytokines, particularly in resistant-background mice, does not necessarily prevent the development of a $\mathrm{T}_{\mathrm{H}} 1$ response. Nevertheless, the $\mathrm{T}_{\mathrm{H}} 2$ response dominates the clinical outcome, presumably as a result of powerful deactivating effects on infected cells.

\section{Box 1 | Variables of the Leishmania major infection model}

The conventional Leishmania major mouse model uses a high dose of parasites, usually stationary-phase promastigotes, injected into a subcutaneous site (shaved rump or hind footpad). Several variables have been introduced to the model, which, in some cases, have altered the outcome. These include the developmental stage of the parasites used for injection (purified metacyclic promastigotes compared with heterogeneous populations of stationary-phase promastigotes ${ }^{122}$ ), the injection of a small number of parasites ${ }^{44}$, alternative routes of inoculation (including intravenous, intradermal and intranasal routes ${ }^{14,35,36}$ ) and a natural form of infection using the sandfly vector ${ }^{119}$. The $L$. major substrains that are used might influence the outcome of infection also ${ }^{49}$. Substrains of $L$. major used in mouse models can be derived from human or rodent isolates, and they are classified generally in terms of their geographic origin. Also, L. major substrains might undergo spontaneous variations owing to routine passages or length of time in culture. Some of the common L. major substrains that are used in mouse models are Friedlin (Jordan Valley, WHOM/IL/80/FN), IR173 (Iran, WHOM/IR/-173), LV39/Neal (southern Russia, MRHO/SU/59/P), NIH/Seidman (West Africa, MHOM/SN/74/S), World Health Organization reference strain 5-ASKH (Turkmenskaya, MHOM/SU/73/5-ASKH) and CC-1 (Iran, MHOM/IR/83/LT252). 


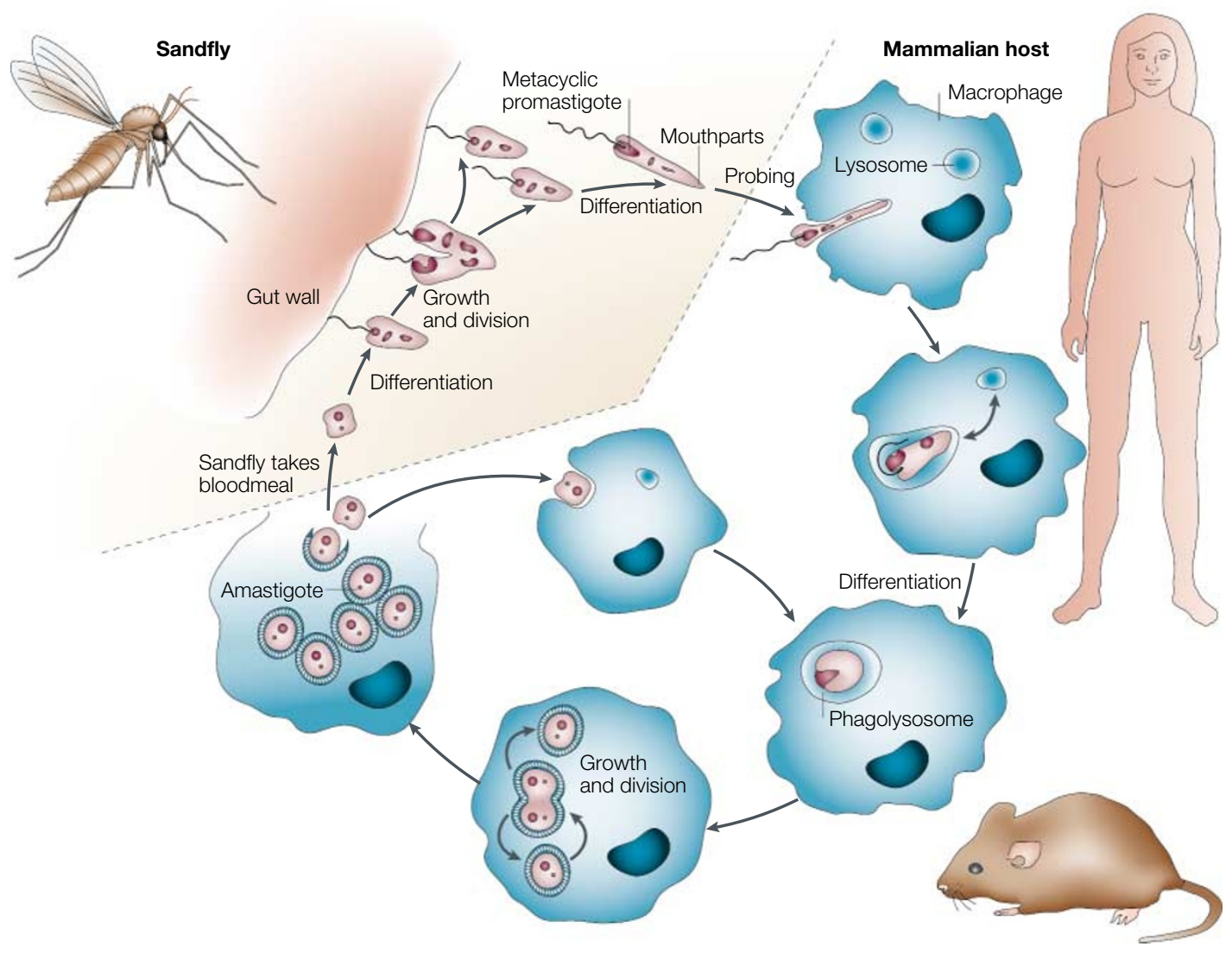

Figure 1 | Life cycle of Leishmania major infection. Leishmania parasites are transmitted by the bites of infected female sandflies, which inject a small number of infectious-stage, metacyclic promastigotes into the skin. These forms are opsonized efficiently by serum components and taken up by macrophages, where they reside in phagolysosomes and transform into replicating amastigotes. Infected macrophages are taken up by sandflies during blood feeding; they are lysed in the fly midgut, releasing parasites that transform into rapidly dividing, non-infectious-stage promastigotes. These forms undergo a process of attachment to the midgut wall, release and anterior migration that is accompanied by their differentiation to non-dividing, metacyclic promastigotes that can be transmitted when the sandfly takes another blood meal.

REACTIVE NITROGEN INTERMEDIATES (RNIs). Primarily nitric oxide, these are generated by nitrogen oxidation of $\mathrm{L}$-arginine, and can have potent activity to destroy intracellular pathogens such as Leishmania.
For example, the production of REACTIVE NITROGEN INTERMEDIATES (RNIs) by IFN- $\gamma$-activated macrophages is known to be inhibited by IL-4, IL-10, IL-13 and transforming growth factor- $\beta$ (TGF- $\beta)^{23}$, and the downregulation of these cytokines might be crucial to the development of acquired resistance (see below).

IL-12: redirecting the early $T_{H} 2$ response. The ability of exogenous IL- 12 to redirect the early $\mathrm{T}_{\mathrm{H}} 2$ response to L. major in $\mathrm{BALB} / \mathrm{c}$ mice and to promote resistance is well supported ${ }^{24,25}$, as is the effect of genetic disruption of IL-12 on upregulating the expression of IL-4 and establishing progressive disease in normally resistant mice ${ }^{14,26}$. A stronger, more sustained $\mathrm{T}_{\mathrm{H}} 2$ response and disease exacerbation have been observed also in resistant mice treated with anti-IL-12 antibodies ${ }^{17,24}$, although unless the treatment is maintained, the IL-12 response recovers and the infection is controlled. The fact that anti-IL-12 antibody treatment has the greatest effect when delayed until seven days after infection ${ }^{17}$ reinforces the findings from IL-12-deficient C57BL/6 mice after a low-dose challenge, in which parasite growth was identical to that in wild-type mice over the first 4-5 weeks ${ }^{14}$. This indicates that the production of IL-12 is delayed normally even in resistant mice. The inability of L. major to drive early IL-12 production in either resistant or susceptible mouse strains might explain why their initial response to $L$. major defaults to a $\mathrm{T}_{\mathrm{H}} 2$ pathway.

Sustained $T_{H}$ 2-cell dominance in BALB/c mice. If IL-12 production is necessary to redirect the early $\mathrm{T}_{\mathrm{H}} 2$ response, then some failure of this response pathway in $\mathrm{BALB} / \mathrm{c}$ mice seems likely to underlie their susceptibility to L. major (FIG. 5). Selective loss of IL-12 signalling owing to downregulated expression of the IL-12 receptor $\beta 2$-chain (IL-12R $\beta 2$ ) has been proposed to explain the defective IL-12 response in BALB/c mice ${ }^{27}$. The IL-12R comprises two components, IL-12R $\beta 1$ and IL-12R $\beta 2$, which are both expressed by T cells after TCR engagement. The instability of IL-12R $\beta 2$ expression in BALB/c mice is thought to occur through an IL-4-dependent process ${ }^{28}$ and an as-yet-undefined, genetically controlled IL-4-independent mechanism ${ }^{29}$. The relevance of this process has been questioned, however, by the finding that $\mathrm{BALB} / \mathrm{c}$ mice that express an IL-12R $\beta 2$ transgene maintain a non-healing phenotype, despite stable IL-12 signalling and the activation of signal transducer and activator of transcription 4 (STAT4) ${ }^{30}$. 


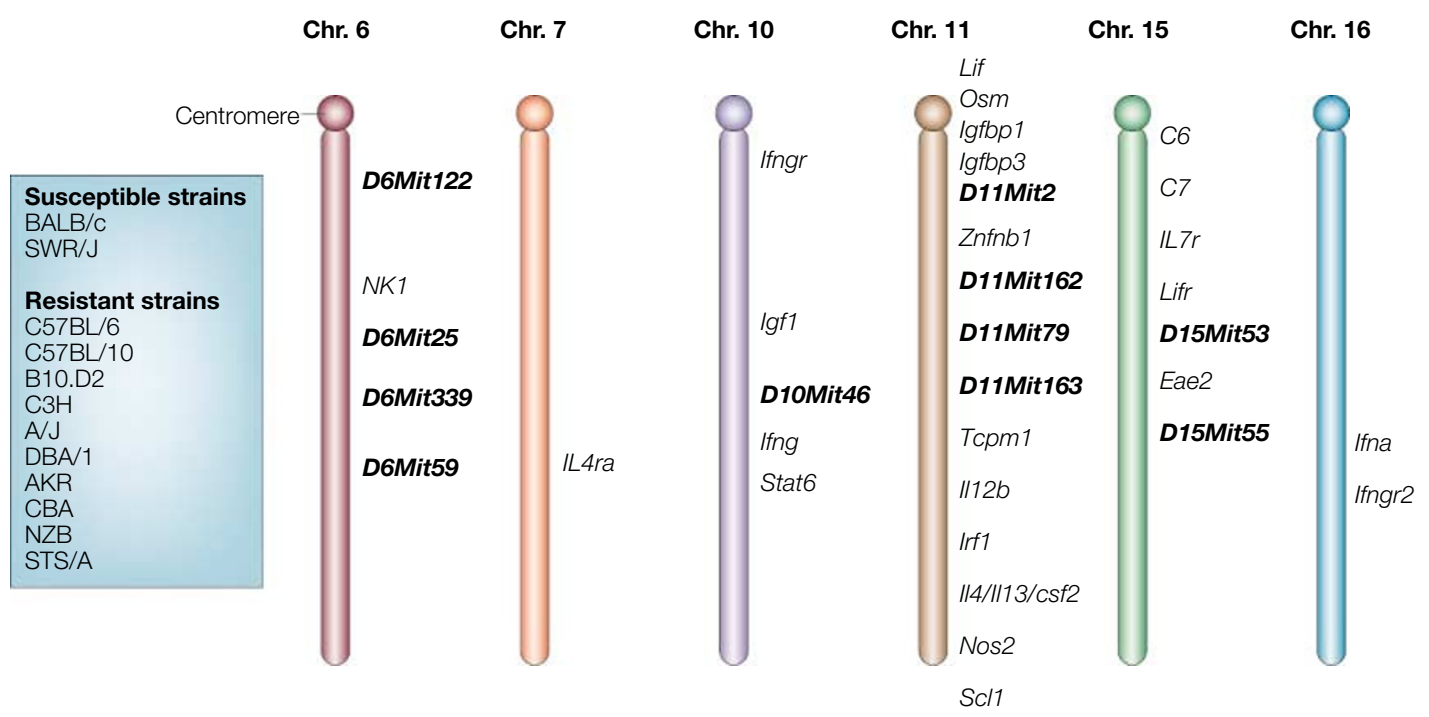

Figure 2 | The genetics of resistance to Leishmania major. Several mouse loci have been found to be associated with resistance to $L$. major infection. The linkage data shown were compiled from studies of infection of recombinant inbred strains $^{49,129}$ or serial backcross mapping ${ }^{48}$, and they are based on measurements of lesion size. The loci in bold are the markers that were found to be linked highly to resistance. The plausible candidate genes that are located on these chromosomes or have been mapped in the marker regions are shown also. However, it should be noted that no polymorphisms of these candidate genes have been identified that would indicate resistance to $L$. major infection. The placement of loci in relation to the centromeres represents the relative order of the loci and not the actual map distances. For information on the actual maps and gene symbols see the Mouse Genome Informatics website. Chr., chromosome.

The inflammatory or tissue environment in which the early $\mathrm{T}_{\mathrm{H}} 2$ response is induced might also preclude its extinction in $\mathrm{BALB} / \mathrm{c}$ mice. For example, neutrophils which are maintained for several weeks as a high proportion of the inflammatory infiltrate in the inoculated footpad of $\mathrm{BALB} / \mathrm{c}$ mice, but only transiently in $\mathrm{C} 57 \mathrm{BL} / 6$ mice $^{31}$ - might contribute to the sustained induction of a $\mathrm{T}_{\mathrm{H}} 2$ response, because depletion of neutrophils at the time of L. major challenge in BALB/C mice inhibited the IL- 4 response and promoted partial resistance $^{32}$. Additional host-strain differences have been found in the manner in which parasites disseminate from the site of inoculation to the draining lymph nodes and visceral organs; dissemination occurs rapidly in $\mathrm{BALB} / \mathrm{c}$ mice, whereas early parasite containment in the footpad and draining lymph nodes is observed in resistant mice ${ }^{33}$. As a result of this dissemination, $\mathrm{CD}^{+}$ $\mathrm{T}$ cells that produce IL- 4 spontaneously in vitro can be found in the liver and spleen of BALB/c mice two weeks after infection, whereas these cells are not found in the viscera of C57BL/6 mice ${ }^{34}$. The same distinctive patterns of early parasite trafficking have been observed recently in a comparison of BALB/c SCID and C57BL/6 SCID mice, which indicates that the differences are not secondary to an adaptive immune response (T. Kamala and P. Matzinger, personal communication).

That the site of antigen delivery can influence T-cell priming has been shown clearly in the L. major model; parasites that are delivered intravenously or intranasally can elicit sustained $\mathrm{T}_{\mathrm{H}} 2$ responses and produce nonhealing infections in normally resistant mice ${ }^{35,36}$. This indicates that owing to differences in parasite dissemination between resistant and susceptible mice, distinct populations of dendritic cells (DCs) with the capacity to induce preferential priming of either $\mathrm{T}_{\mathrm{H}} 1$ or $\mathrm{T}_{\mathrm{H}} 2$ cells might become activated. The existence of tolerogenic or $\mathrm{T}_{\mathrm{H}} 2$-inducing DCs in peripheral tissues has been indicated strongly by studies of DCs derived from the liver, lung and Peyer's patches ${ }^{37}$. Such populations might not be distinct lineages of antigen-presenting cell (APC), but might, instead, be owing to the modulation of APC function by specific tissue environments (such as cytokines and chemokines). It is, for example, possible that the chemokine monocyte chemotactic protein 1 (MCP1; also known as CCL2) - the deletion of which prevents $\mathrm{T}_{\mathrm{H}} 2$-cell polarization and confers partial resistance to L. major infection in $\mathrm{BALB} / \mathrm{c}$ mice $^{38}-$ might be overexpressed in certain tissues of susceptible mouse strains. Finally, the observations that interactions between co-stimulatory molecules and their receptors (such as cytotoxic T-lymphocyte antigen 4 (CTLA4)/CD28-B7 (REFS 39-41) and OX40-OX40L 42) can, under certain conditions, have crucial roles in the development of a $\mathrm{T}_{\mathrm{H}} 2$ response to L. major in vivo raise the possibility that the differential expression of these co-stimulatory molecules might define functionally distinct subsets of APC in different tissues.

As skin-derived DCs that can produce IL-12 p40 in response to $L$. major in vitro and prime for protective T-cell responses in vivo are readily obtainable from $\mathrm{BALB} / \mathrm{c} \mathrm{mice}^{43}$, it does not seem that the IL-12 defect in $\mathrm{BALB} / \mathrm{c}$ mice is intrinsic to these cells. This is reinforced by the important observation that $\mathrm{BALB} / \mathrm{c}$ mice develop stable resistance to small parasite inocula in a subcutaneous site ${ }^{44}$. A small number of parasites administered to $\mathrm{BALB} / \mathrm{c}$ mice might mimic the events 


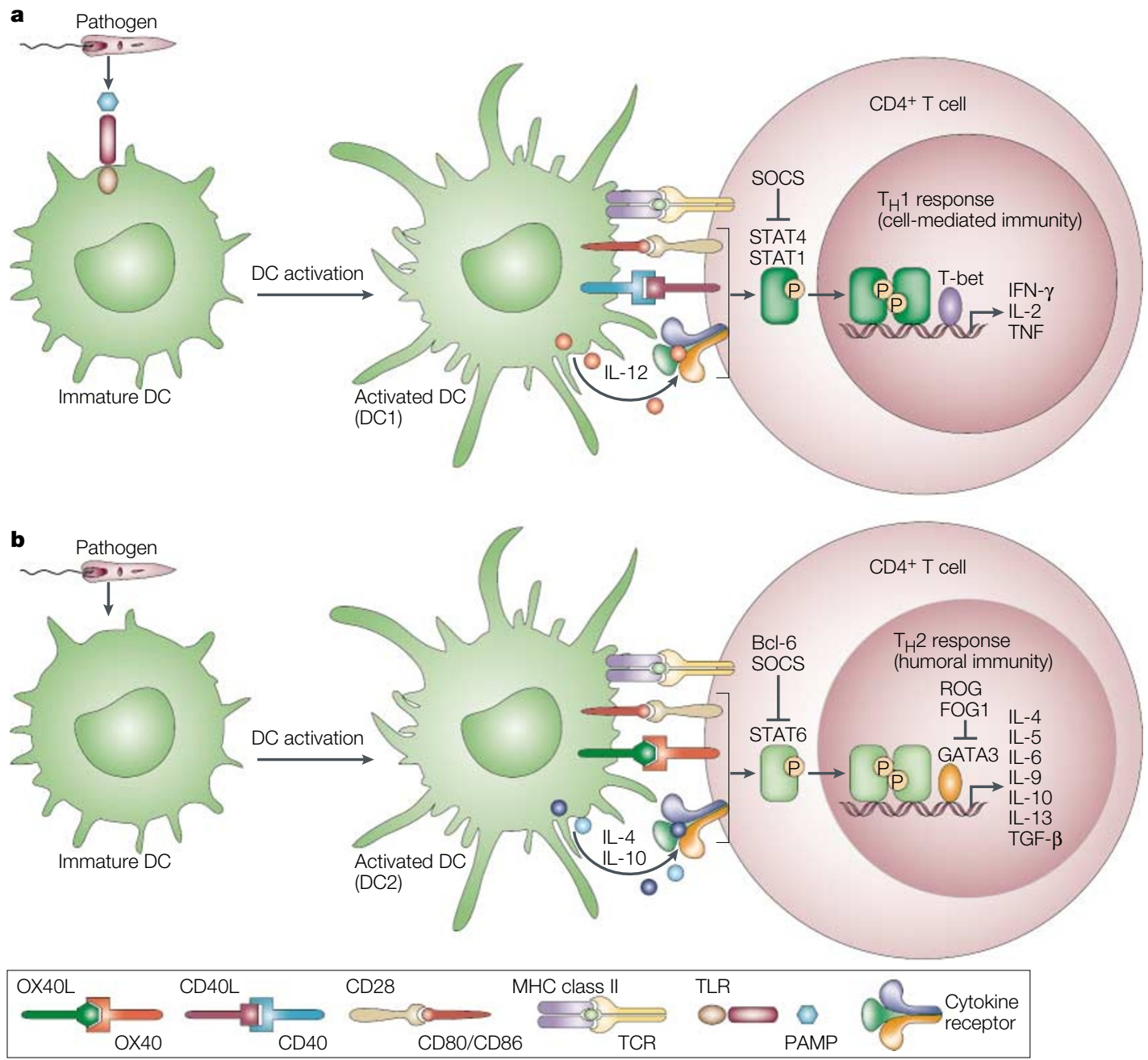

Figure $3 \mid$ Model of $T_{H} 1-T_{H}$ 2-cell development. For both $T$ helper $1\left(T_{H} 1\right)$ - and $T_{H}$ 2-cell differentiation, antigens are presented to naive $C D 4^{+} T$ cells by dendritic cells (DCs). The interaction of co-stimulatory molecules with their respective ligands (CD40-CD4OL, OX40-OX40L and/or CD80-CTLA4/CD28), together with the local cytokine environment, promotes the differentiation of naive T cells into interferon- $\gamma(\mathrm{IFN}-\gamma)$-secreting $\mathrm{T}_{H} 1$ cells or interleukin-4 (IL-4)-secreting $\mathrm{T}_{\mathrm{H}} 2$ cells. It has been proposed also that distinct subsets of dendritic cells, known as DC1 and DC2, might exist, which, in turn, direct $T_{H} 1$ and $T_{H} 2$ differentiation pathways, respectively. $\mathbf{a} \mid \ln T_{H} 1$ cell development, certain pathogens or pathogen-associated molecular patterns (PAMPs) trigger antigen-presenting cells, through Toll-like receptors (TLRs), to secrete IL-12, which promotes the differentiation of naive T cells into IFN- $\gamma$-secreting $T_{H} 1$ cells. Signal transducer and activator of transcription 4 (STAT4) and STAT1 are activated by IL-12 and IFN- $\gamma$, respectively. T-bet, a T-box transcription factor is $\mathrm{T}_{H} 1$-lineage specific. $\mathbf{b} \mid \ln \mathrm{T}_{H} 2$-cell development, the inability of antigen to activate $\mathrm{DCs}$ to produce $\mathrm{LL}-12$ results in a default pathway of naive T-cell differentiation into IL-4-secreting $\mathrm{T}_{H} 2$ cells. In addition, antigen and/or specific tissue environments might activate DCs to produce IL-4 or IL-10, which will instruct T 2-cell development. STAT6 is activated specifically by IL-4-receptor binding. The $T_{H}$ 2-lineage-specific transcription factor GATA3 binds to consensus GATA-binding sites (AGATAG). The factors c-Maf and NFATc (nuclear factor of activated T cells) have been associated with T 2 differentiation also. Bcl-6, ROG (repressor of GATA) and FOG1 (friend of GATA1) negatively regulate $T_{H} 2$ differentiation by repressing the activity of STAT6 and GATA3. Suppressor of cytokine signalling (SOCS)-family members inhibit $\mathrm{T}_{\mathrm{H}} 1$ and $\mathrm{T}_{\mathrm{H}} 2$ responses by blocking STAT activity. CTLA4, cytotoxic T-lymphocyte antigen 4; TCR, T-cell receptor; TGF- $\beta$, transforming growth factor- $\beta$; TNF, tumour-necrosis factor.

that occur normally in resistant mice, in which there is no dissemination of parasites beyond the local draining lymph nodes. It is interesting that the successful immunization of $\mathrm{BALB} / \mathrm{c}$ mice using irradiated L. major promastigotes depends crucially on a high dose and intravenous route of injection ${ }^{45}$. There is evidence to indicate that the protection induced in this model is due not to immunization per se, but to tolerization of the L. majorspecific $\mathrm{CD} 4^{+} \mathrm{T}$ cells that would normally be activated along a $\mathrm{T}_{\mathrm{H}} 2$ developmental pathway in the viscera ${ }^{46}$.
Such inherent host-strain differences in parasite dissemination and inflammation might be relevant to the observation that cells in the non-T-cell compartment ${ }^{9}$ and at least six genetic loci contribute to resistance to L. major ${ }^{47,48}$ (FIG. 1).

IL-4-independent $T_{H} 2$ pathways. Although an early $\mathrm{T}_{\mathrm{H}} 2$ response might not be the distinguishing event in the development of non-healing disease in BALB/c mice, there is little doubt that a sustained $\mathrm{T}_{\mathrm{H}} 2$ response 


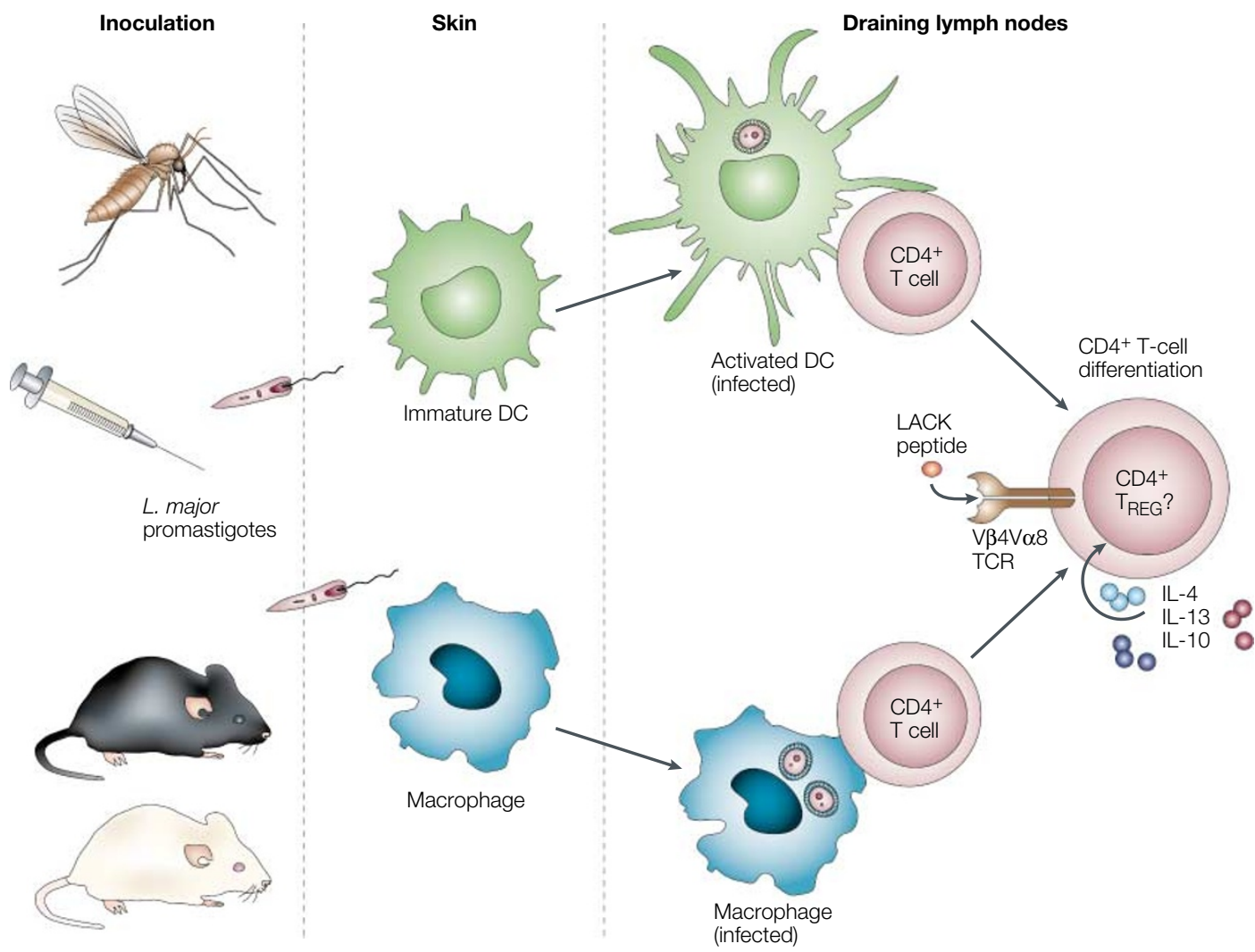

Figure 4 | Early events in susceptible and resistant mice. In both susceptible and resistant mouse strains, inoculation of Leishmania major metacyclic promastigotes by needle or by infected sandflies results in the early production of interleukin-4 (IL-4) and other type-2 cytokines by CD4+ $T$ cells in lymph nodes draining the site of infection. The early $T$ helper $2\left(T_{H} 2\right)$ response is due, in part, to the activation of an oligoclonal population of $T$ cells expressing a $V \beta 4 \mathrm{~V} \alpha 8 \mathrm{~T}$-cell receptor (TCR) that recognizes the LACK (Leishmania homologue of receptors for activated C kinase) peptide. These cells might be pre-committed to produce IL-4 and IL-10 - possibly, they are regulatory $T$ cells $\left(T_{\mathrm{REG}}\right)$ - or they might default to the $T_{H} 2$ pathway owing to the absence of $L$. major-driven $\mathrm{IL}-12$ production by macrophages or dendritic cells.

is responsible ultimately for this outcome. There are, however, accumulating data to indicate that the IL-4 component of this response is not sufficient and, in some cases, not necessary for susceptibility (FIG. 5). Using genetically pure BALB/c IL-4- or IL-4R $\alpha$-deficient mice, it was shown that infection with the L. major substrain IR173 was controlled only partially in the IL-4-deficient mice, but highly controlled in IL-4R $\alpha$-deficient mice ${ }^{49}$. As the IL- $4 \mathrm{R} \alpha$-chain is shared between the receptors for IL-4 and IL-13, these results indicate a potential role for IL-13 in mediating susceptibility to L. major. Studies in an IL-13-deficient mouse strain, as well as an IL-13transgenic mouse strain, confirmed that IL-13 is a susceptibility factor in L. major infection and that there is an additive effect of deleting both IL-4 and IL-13 (REF. 50). Remarkably, both IL-4-deficient mice ${ }^{51}$ and IL-4R $\alpha$ deficient mice are as susceptible as wild-type mice when infected with another L. major substrain, LV39. A similar lack of resistance to another substrain, $\mathrm{NIH} /$ Seidman, was observed in IL-4-deficient BALB/c mice treated with a soluble IL-13R $\alpha 2-F c$ fusion protein to block the biological activity of IL-13 (REF. 52). So, under some circumstances, IL-4R $\alpha$ signalling is not required for $\mathrm{T}_{\mathrm{H}} 2$ priming to occur, which indicates that other pathways exist to promote parasite survival.
Under some conditions, TGF- $\beta$ has been shown to suppress $T_{H} 1$-cell development and to inhibit macrophage activation. Its role in L. major infection is indicated by the exacerbation of infection in $\mathrm{C} 57 \mathrm{BL} / 6 \times$ $\mathrm{BALB} / \mathrm{c}$ F1 mice treated during the chronic phase with TGF- $\beta$ and, more convincingly, by the enhanced resistance of these mice to infection after treatment with anti-TGF- $\beta$ antibody ${ }^{53}$. Although antibody treatment did not alter the pattern of IL-4 or IFN- $\gamma$ production, it did increase the production of nitric oxide by macrophages in parasitized lesions. An effect of TGF- $\beta$ on the differentiation of $\mathrm{T}_{\mathrm{H}} 1$ cells is indicated by a recent report involving $\mathrm{BALB} / \mathrm{c}$-background mice that express a dominant-negative form of TGF- $\beta$ receptor type II in T cells ${ }^{54}$. Formation of L. major-induced lesions was delayed in these mice and the lesions progressed more slowly. Although the mice had an enhanced $\mathrm{T}_{\mathrm{H}} 1$ response in draining lymph-node cells, they also maintained strong $\mathrm{T}_{\mathrm{H}}$ 2-type cytokine production, which is consistent with the fact that they failed to heal the lesions ultimately.

An additional cytokine that can suppress $T_{H} 1$ responses and the activation of macrophages is IL-10. IL-10 was thought initially not to be important in L. major infection, because treatment of $\mathrm{BALB} / \mathrm{c}$ mice 
Skin

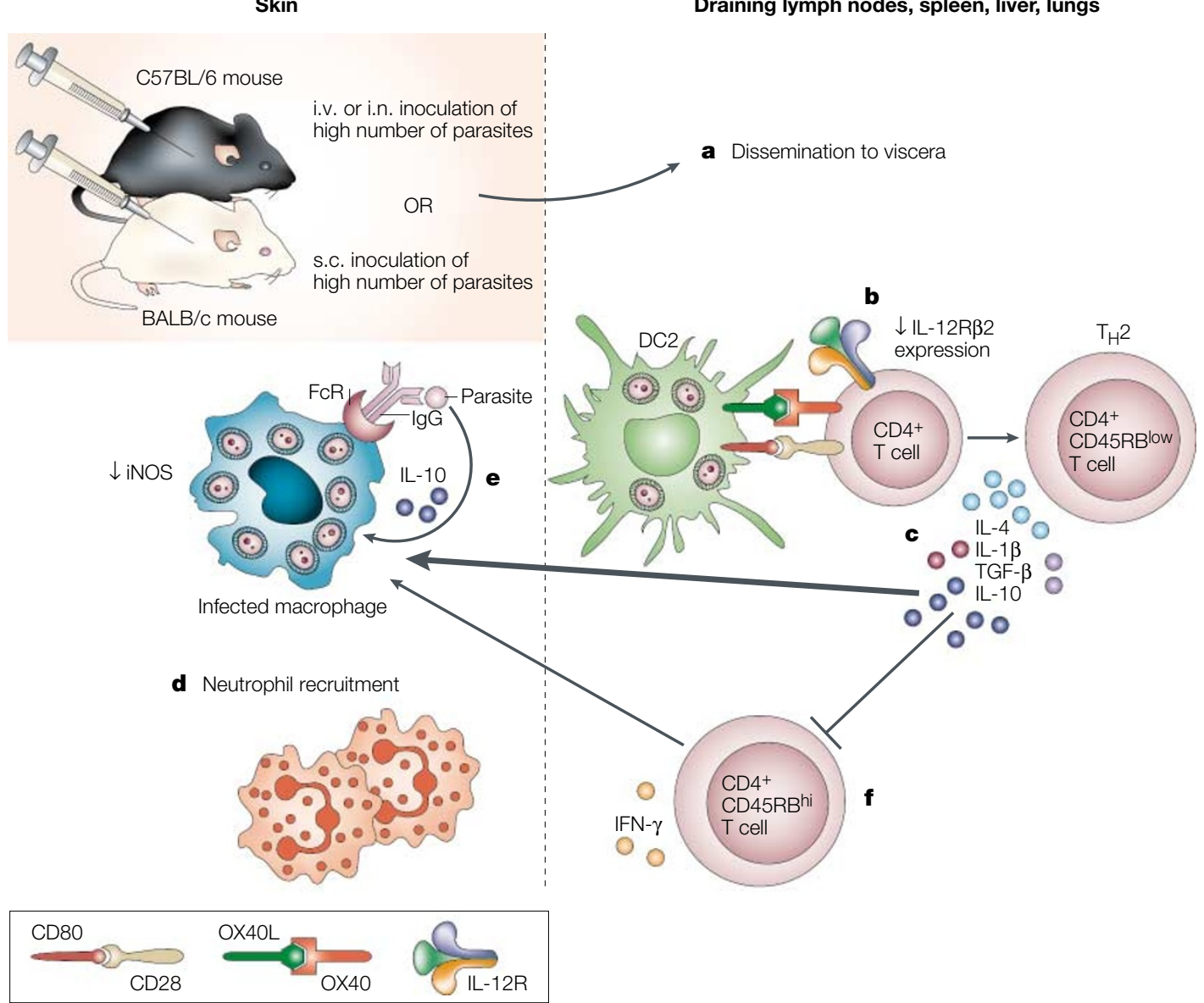

Figure 5 | Late events in susceptible mice. The evolution of susceptibility to Leishmania major, as occurs after sub-cutaneous (s.c.) inoculation of a relatively high number of parasites into BALB/c mice, or intravenous (i.v.) or intranasal (i.n.) inoculation of a high number of parasites into C57BL/6 mice, is due to the failure of an interleukin-12 (IL-12)-dependent redirection of the early Thelper 2 $\left(T_{H} 2\right)$ response, resulting in the clonal expansion and dominance of $C D 4{ }^{+} C D 45 R B^{\text {low }} T_{H} 2$ cells. The $T_{H} 1$-response defect might be due to several mechanisms, including: $\mathbf{a}$ | dissemination of parasites to the viscera, where $T_{H} 2$-priming conditions are maintained. The class of immune response in these tissues might be biased by the presence of lineage-specific type-2 dendritic cells (DC2s) that express the appropriate co-stimulatory molecules and cytokines required to drive $\mathrm{T}_{\mathrm{H}}$ 2-cell development, or by the cytokine milieu that conditions DCs to promote $T_{H} 2$-cell development; and/or b | unstable expression of IL-12 receptor $\beta 2$-chain (IL-12R 32 ) on activated CD4 ${ }^{+} T$ cells. Type-2 cytokines (c) contribute to susceptibility by downregulating $T_{H} 1$-cell differentiation and by conditioning infected macrophages to become unresponsive to activation signals required for nitric oxide (NO)-dependent killing. Sustained neutrophil recruitment to the inflammatory site (d) might be inhibitory to $T$, 1-cell development, owing, for example, to the local secretion of transforming growth factor- $\beta$ (TGF- $\beta$ ) or IL-10. IL-10 produced by macrophages as a consequence of Fc-receptor (FcR) ligation by parasite-specific antibodies (e) might contribute to the pool of deactivating cytokines in infected tissues. A minor population of interferon- $\gamma(\mathrm{IFN}-\gamma)$-producing $\mathrm{CD} 4{ }^{+} \mathrm{CD} 45 \mathrm{RB}{ }^{\mathrm{hi}}$ effector cells (f) remain active even during the progressive stages of disease. lgG, immunoglobulin G; iNOS, inducible nitric oxide synthase.

with an anti-IL-10 monoclonal antibody had little effect on reversing disease progression ${ }^{22,55}$. However, the role of IL-10 in L. major susceptibility needs to be reconsidered in the light of several recent studies: resistant mice expressing an IL-10-encoding transgene under the control of the MHC class II Ea promoter, which directs the expression of IL-10 mainly to APCs that display MHC class II molecules, were more susceptible to infection with $L$. major ${ }^{21}$; and the stable $\mathrm{T}_{\mathrm{H}} 1$ phenotype that is established in $\mathrm{BALB} / \mathrm{c}$ mice infected with a low dose of L. major could be overcome by transfection of a plasmid encoding IL-4 at the time of challenge, but only if coadministered with a plasmid encoding IL-10 (REF. 56). Conversely, IL-10-deficient mice crossed for several generations to a $\mathrm{BALB} / \mathrm{c}$ background were markedly more resistant to $L$. major infection than wild-type $\mathrm{BALB} / \mathrm{c}$ mice ${ }^{57}$. Most recently, IL-10-receptor blockade has been shown to confer partial resistance to L. major in wild-type $\mathrm{BALB} / \mathrm{c}$ mice, regardless of the L. major substrain (N.N.-T., unpublished observations).

Macrophages have been proposed as an important source of IL-10 in the BALB/c model, on the basis of in vitro findings that Leishmania amastigotes coated with immunoglobulin G mediate ligation of Fc $\gamma$ Rs on macrophages, which, in conjunction with lipopolysaccharide, triggers them to produce large amounts of IL-10 and suppresses the production of IL-12 (REF. 57) (FIG. 5). However, as anti-CD4 antibody treatment abolished the 
expression of IL-10 in lymph-node cells four days after infection ${ }^{15}$ and as depletion of CD4 allowed IL-4deficient mice to control infections with LV39 (REF. 58), it is probable that the crucial source of IL-10 in vivo is $\mathrm{CD}^{+}{ }^{+} \mathrm{T}$ cells. Indeed, $\mathrm{CD} 4^{+} \mathrm{T}$ cells from $L$. majorinfected BALB/c mice express high levels of both IL-4 and IL-10 messenger RNA ${ }^{15}$, and the $\mathrm{CD}^{+}{ }^{+} \mathrm{T}$ cells that suppress $L$. major immunity in $\mathrm{BALB} / \mathrm{c}$ mice were found to belong to an IL-4- and IL-10-producing population of cells that were CD45RB ${ }^{\text {low }}$ and also inhibited colitis ${ }^{22}$. In light of the well-described phenotype and function of naturally occurring $\mathrm{CD}^{4}{ }^{+} \mathrm{CD} 25^{+} \mathrm{CD} 45 \mathrm{RB}^{\text {Low }}$ REGULATORY T CELLS ${ }^{59}$, it seems possible that the $\mathrm{T}_{\mathrm{H}} 2$ cells that are responsible for progression of L. major infection might be activated from a distinct lineage of IL-4- and IL-10-secreting immunoregulatory T cells (FIG. 5).

The relative contributions of $T_{H} 2$ cytokines. The results from IL-4- and IL-4R $\alpha$-deficient BALB/c mice seem to undermine a basic tenet of the $T_{H} 1 / T_{H} 2$ model regarding the instructional role of IL-4 in $\mathrm{T}_{H}$ 2-cell development. It is now clear, however, that IL-4R $\alpha$-STAT6 signalling is not essential for priming $\mathrm{CD} 4{ }^{+} \mathrm{T}$ cells to produce $\mathrm{T}_{\mathrm{H}} 2$ cytokines in vivo, because in STAT6- or IL-4R $\alpha$-deficient mice, $\mathrm{T}_{\mathrm{H}} 2$ responses are decreased, but significant amounts of IL-4 and other $\mathrm{T}_{\mathrm{H}} 2$-related cytokines are still present $t^{60}$. Given the redundancy of $\mathrm{T}_{\mathrm{H}} 2$ cytokines able to inhibit $\mathrm{T}_{\mathrm{H}} 1$ responses and/or macrophage activation, and given the inherent $T_{H} 1$-cell developmental defects that have been ascribed to BALB/c mice, it is, perhaps, not surprising that IL-4 production and IL-4R signalling are not required for susceptibility to L. major in these mice. These outcomes should not, however, be interpreted to indicate that the IL-4-IL-4R pathway does not contribute to susceptibility in every case that it remains intact. It might be possible to reconcile the data by using a more rigorous definition of 'resistance.' Often, the term has been applied to mice that can control progressive lesion development, whether or not they actually heal or have a marked reduction in parasite load over time. A careful quantitative analysis of parasite load at the inoculation site has shown that, regardless of the L. major strain used for challenge, impairment of IL-4, IL-10 or IL-13 responses individually does not achieve the same level of resistance to infection as seen in IL- $4 R \alpha-$ deficient mice. In turn, IL-4R $\alpha$-deficient mice are not as resistant as IL-4R $\alpha$ and IL-10 double-deficient mice or IL-4R $\alpha$-deficient mice treated with anti-IL-10R antibody, which have a resistant phenotype comparable to that of C57BL/6 mice (N.N.-T., unpublished observations). It is not known why certain L. major substrains (for example, LV39) require a more global reduction in $\mathrm{T}_{\mathrm{H}} 2$ cytokines, as is achieved by anti-CD4 antibody treatment, to be controlled. As these substrains do not seem to induce higher levels of these cytokines ${ }^{49}$, they might have a preference for replicating in cell types that are more sensitive to the effects of deactivating cytokines. Alternatively, they might have intrinsically greater resistance to immune-mediated killing mechanisms, and therefore require a greater increase in the $\mathrm{T}_{H} 1: \mathrm{T}_{H} 2$ cytokine ratio for killing to occur.
Finally, to what extent do the factors that control susceptibility to L. major infection in BALB/c mice also operate in non-healing and/or systemic forms of human disease? In this context, the overproduction of IL-10 as has been detected in chronic cutaneous lesions ${ }^{61}$, in lesion tissue from kala-azar patients ${ }^{62}$ and in plasma from patients with post-kala-azar dermal leishmaniasis $^{63}$ - seems to provide a much better correlate of susceptibility than production of IL-4. It has not been determined whether $\mathrm{CD} 4^{+} \mathrm{T}$ cells produce the IL-10 in these clinical settings.

\section{$T_{H}$ 1-cell development and resistance}

Regulation of $T_{H} 1$ responses. Advances in gene-knockout and transgenic technologies have been particularly helpful in advancing our understanding of the pathways that are involved in the induction of acquired immunity to L. major in resistant mice; they have not, however, fundamentally altered the view that type- 1 cytokines, particularly IFN- $\gamma$, are essential and will be the key to vaccine development and immunotherapy for leishmaniasis (FIG. 6). Consistent with the concept of inflammatory type- 1 cytokines as mediators of protection, the genetic ablation of cytokines (IL-12, IFN- $\gamma$ and tumour-necrosis factor, TNF), receptors (IFN- $\gamma \mathrm{R}$ ), transcription factors (T-bet and STAT4) or co-stimulatory molecules (CD40-CD40L) that are involved in the development or function of $\mathrm{T}_{\mathrm{H}} 1$ cells will lead to susceptibility to $L$. major. For mice that are deficient in IL-12 (REF. 26), IFN- $\gamma^{64}$, T-bet ${ }^{65}$ or CD40-CD40L interactions ${ }^{66,67}$, the immune response to $L$. major defaults to the $\mathrm{T}_{\mathrm{H}} 2$ pathway, which is associated with defective IL-12 production. In the case of mice that are deficient in IFN- $\gamma \mathrm{R}^{68}$ or STAT4 (REF. 69), no $\mathrm{T}_{\mathrm{H}} 2$ default response was observed, which indicates that the impaired production or activity of effector cytokines, rather than the upregulation of expression of deactivating cytokines, is responsible for their inability to heal. Alternatively, in the absence of IL-12 signalling, other $\mathrm{T}_{\mathrm{H}} 1$-inducing cytokines, such as IL-18, might inhibit the $\mathrm{T}_{\mathrm{H}} 2$ default response. Indeed, the IL-4 response to $L$. major was enhanced in IL-18-deficient mice $^{70}$, as was the early growth of parasites in these mice. It is clear, however, that in the absence of IL-12, IL-18 is not sufficient to drive immunity to L. major, and it is not required in IL-12-competent mice, because IL-18-deficient C57BL/6 mice were able to heal ultimately and to extinguish the IL- 4 response that is induced early after infection in these mice ${ }^{70}$. It seems probable that the susceptibility to L. major of IL-18deficient mice reported in the study by Wei et al. ${ }^{71}$ was a result of the early termination of the experiment before the mice had had a chance to heal. An additional $\mathrm{T}_{\mathrm{H}} 1$-response pathway involving the class-1 cytokine receptor WSX1 has been found to influence resistance to $L$. major in a manner similar to IL-18 (REF. 72). Taken together, these data indicate that although alternative factors can cooperate with IL-12 to redirect the early $\mathrm{T}_{\mathrm{H}} 2$ response and can affect the early stages of $L$. major infection in resistant mice, IL-12-IL-12R signalling is essential to establish and maintain a curative $\mathrm{T}_{\mathrm{H}} 1$ response. 


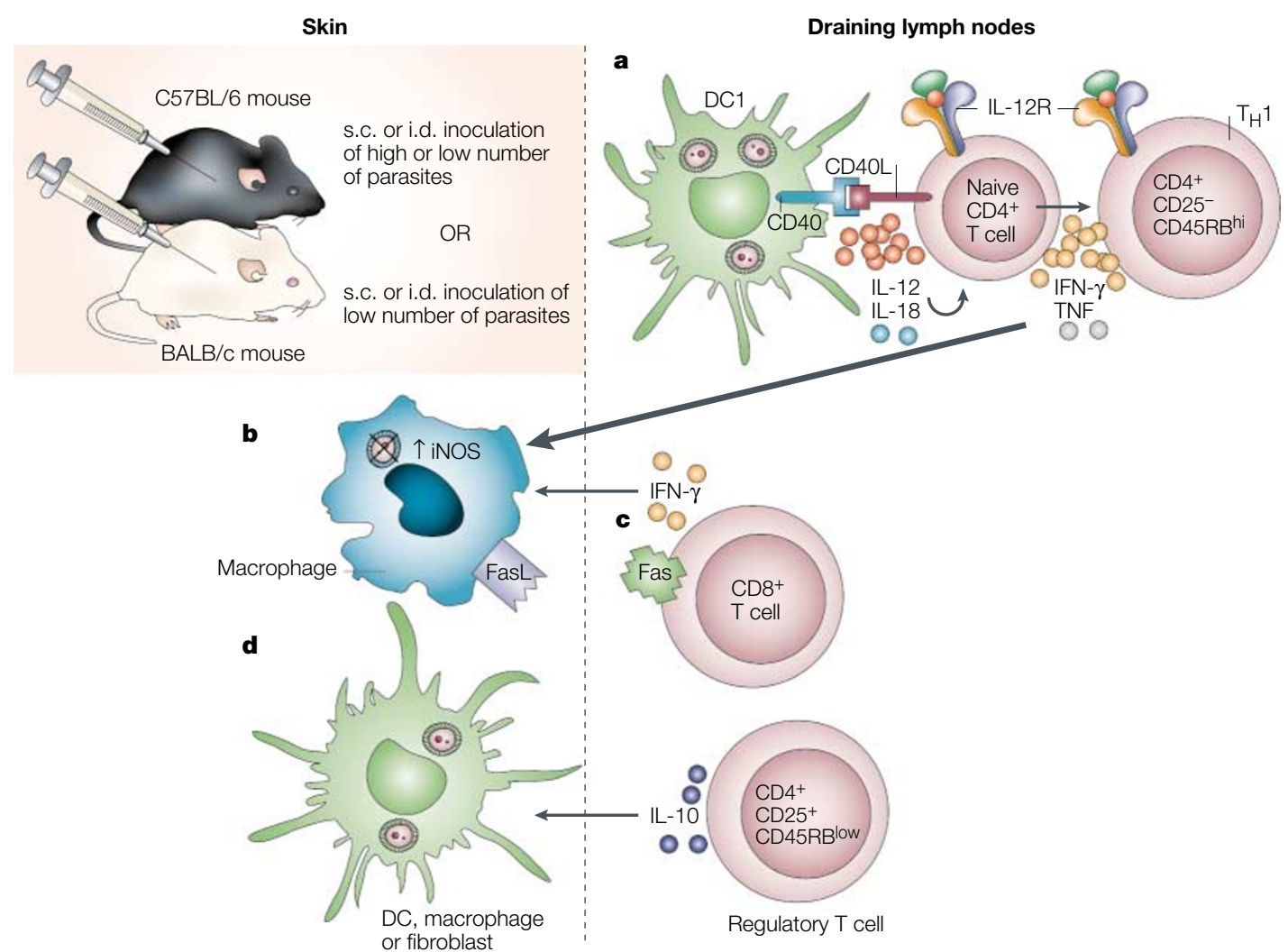

Figure 6 | Late events in resistant mice. The evolution of resistance to Leishmania major, as occurs after sub-cutaneous (s.c.) or intradermal (i.d.) inoculation of a high or low number of parasites in C57BL/6 mice, or a low number of parasites in BALB/c mice, also involves the early production of interleukin-4 (IL-4) and other type-2 cytokines by CD4+ $T$ cells. However, the parasites remain restricted to the site of infection and to the local draining lymph nodes, where, in response to accumulating amastigotes and endogenous agonists such as CD40L and interferon- $\gamma$ (IFN- $\gamma$ ), dendritic cells (DCs) are activated to upregulate expression of CD40 and other co-stimulatory molecules and to produce IL-12 (a). These local priming conditions generate a predominant Thelper 1 $\left(T_{H} 1\right.$ ) response characterized by $C D 4{ }^{+} C D 25-C D 45 R B^{\text {hi }}$ effector cells that produce high levels of IFN- $\gamma$ and tumour-necrosis factor (TNF) to upregulate the expression of inducible nitric oxide synthase (iNOS) and activate infected macrophages for intracellular killing (b). $\mathrm{CD}^{+} \mathrm{T}$ cells cooperate to control infection by their production of IFN- $\gamma$ and by their Iytic activities, which might be mediated by a Fas-Fas ligand (FasL)-dependent pathway (c). After healing, low numbers of amastigotes persist at the site of infection in macrophages, DCs and fibroblasts, owing to the production of IL-10 by CD4+CD25+regulatory T cells (d).

The L. major model has been particularly useful to clarify the role of IL-12 in not only initiating the development of a $\mathrm{T}_{\mathrm{H}} 1$ response, but maintaining a $\mathrm{T}_{\mathrm{H}} 1$ response once it has been established. In particular, IL-12-deficient mice treated transiently with IL-12 develop progressive lesions eventually ${ }^{73}$, and the lesions of healed C57BL/6 mice harbouring persistent parasites reactivate after treatment with anti-IL-12 antibodies $^{74}$. Most convincingly, primed $\mathrm{T}_{\mathrm{H}} 1$ cells from healed mice cannot transfer immunity to IL-12-deficient mice ${ }^{73}$. It seems probable that IL-12 is required to prevent the differentiation of newly emerging uncommitted precursors to $\mathrm{T}_{\mathrm{H}} 2$ cells, because the conditions that promote the early $\mathrm{T}_{H} 2$ response at the time of infection, before the onset of IL-12 production, will be re-established at later times whenever IL-12 is depleted ${ }^{75}$.

Given its central role in reconditioning the adaptive immune response, the source of IL-12 is an important issue to address. Although macrophages ingest Leishmania efficiently, they are not activated by ingestion and their ability to produce IL-12 in response to strong pro-inflammatory stimuli is selectively impaired ${ }^{15,76,77}$.
This might explain the delayed onset of immunity in resistant mice, particularly after low-dose challenge ${ }^{14}$, because macrophages are the primary targets of infection. In contrast to macrophages, mouse DCs, including epidermal Langerhans cells (LCs), take up L. major parasites, acquire a mature phenotype and release IL-12 $\mathrm{p} 40$ in vitro ${ }^{78-80}$. Their role in producing IL-12 in vivo and promoting the development of L. major-specific $\mathrm{T}_{\mathrm{H}} 1$ immunity has been shown also ${ }^{14,43,81}$. The ability of LCs to transport L. major from infected skin to the draining lymph nodes ${ }^{82}$ is thought to rely, at least in part, on the expression of CC-chemokine receptor 2 (CCR2), because resistant-background mice deficient in CCR2 are highly susceptible to L. major infection, and LC migration is impaired markedly in these mice ${ }^{83}$.

Natural killer (NK) cells are an additional cellular component of the innate immune response that have been implicated in the development of a $\mathrm{T}_{\mathrm{H}} 1$ response, primarily through their ability to produce IFN- $\gamma$, which can optimize the production of IL- 12 by DCs and the expression of IL-12R by activated T cells. Rapid development of a $\mathrm{T}_{\mathrm{H}} 1$ response and the early control of 
L. major infection after high-dose footpad injection, as occurs in $\mathrm{C} 3 \mathrm{H}$ mice, is associated with an early NK-cell response, whereas $\mathrm{C} 57 \mathrm{BL} / 6$ and $\mathrm{BALB} / \mathrm{c}$ mice that lack an early NK-cell response have delayed or absent development of a $\mathrm{T}_{\mathrm{H}} 1$ response, respectively ${ }^{84}$. It is clear, however, that although early NK-cell activity might influence the kinetics of the $T_{H} 1$ response, these cells are not required ultimately for resistance, because immune-deficient, T-cell-reconstituted mice that lack NK cells selectively have efficient IL-12-dependent IFN- $\gamma$ production by $\mathrm{CD}^{+} \mathrm{T}$ cells and heal their lesions ${ }^{85,86}$.

Effector molecules in acquired resistance. In addition to deficiencies in $\mathrm{T}_{\mathrm{H}} 1$ cytokines that are essential to redirect the $T_{H} 2$ response along a $T_{H} 1$ developmental pathway, animals with defects in effector molecules that are involved in macrophage activation and microbicidal response pathways are susceptible to $L$. major. The upregulation of expression of inducible nitric oxide synthase (iNOS) and the subsequent production of RNIs in response to activation by IFN- $\gamma$ has, in many systems (including L. major infection), been thought to use TNF as a co-factor ${ }^{87}$, and animals that are deficient in either $\mathrm{iNOS}^{88}$ or $\mathrm{TNF}^{89}$ cannot control infection. Interestingly, TNFR1- and TNFR2-deficient mice can control parasite replication, although they fail to resolve their lesions ${ }^{90}$, which indicates that TNF signalling can be compensated for through a third receptor, but that the ligand is needed to confer protection. The induction of iNOS and production of nitric oxide seem not to be sufficient for microbicidal function, as mice deficient in Fas (CD95) or Fas ligand (FasL) cannot eliminate L. major despite enhanced production of nitric oxide ${ }^{91,92}$. On the basis of these findings, it was concluded that the apoptosis of infected macrophages through the Fas-FasL pathway might contribute to host resistance.

Role of $C D 8^{+} T$ cells. With regard to the T-cell subsets that are involved in acquired resistance to $L$. major, the crucial role of $\mathrm{CD} 4^{+} \mathrm{T}$ cells has been a consistent finding ${ }^{14,93,94}$. The requirement for $\mathrm{CD}^{+} \mathrm{T}$ cells, however, is a recent observation that does not agree with earlier studies. Although $\mathrm{CD} 8^{+} \mathrm{T}$ cells were shown to be important for immunity to re-infection in mice that had healed their primary lesions ${ }^{95}$, C57BL/6 mice deficient in $\beta 2$-microglobulin or $\mathrm{CD} 8$ maintained their ability to heal ${ }^{96}$, as did anti-CD8 antibody-treated mice ${ }^{97}$, which indicates that $\mathrm{CD}^{+} \mathrm{T}$ cells are not required for the control of primary infection involving a high-dose, subcutaneous challenge. By contrast, using a challenge system that reproduces two key features of natural transmission - low dose (100 metacyclic promastigotes) and intradermal inoculation (in the mouse ear dermis) - the outcome of $L$. major infection in anti-CD8 antibodytreated and CD8-deficient mice showed that, in addition to $\mathrm{CD} 4^{+} \mathrm{T}$ cells, $\mathrm{CD} 8^{+} \mathrm{T}$ cells are required for the control of primary L. major infection in the $\operatorname{skin}^{98}$ (FIG. 6). These data are consistent with clinical studies that report high numbers of antigen-specific $\mathrm{CD} 8^{+} \mathrm{T}$ cells in lesions and peripheral blood during the acute stage of lesion formation and during the healing process ${ }^{99,100}$. Although it is assumed that the main protective function of antigenspecific $\mathrm{CD} 8^{+} \mathrm{T}$ cells is to contribute to the release of IFN- $\gamma$ in the L. major-loaded dermis, the cytolysis of infected host cells that are themselves defective in intracellular killing might release parasites and make them available for uptake by cells that are more responsive to activation signals (for example, macrophages). The observations regarding the importance of the Fas-FasL pathway might be relevant to the possible role of $\mathrm{CD}^{+}$ T-cell cytolytic activity in immunity to L. major.

L. major persistence in healed mice. The fact that L. major is sequestered in fibroblasts ${ }^{101}$ and $\mathrm{DCs}^{102}$ has been offered as an explanation for the important observation that latent infections are established in resistant mice after clinical cure ${ }^{103}$. Despite their inability to achieve sterile immunity, healed mice maintain life-long immunity to re-infection. Immune pressure during the chronic phase is maintained by $\mathrm{CD} 4^{+}$and $\mathrm{CD}^{+} \mathrm{T}$ cells, IL-12, IFN- $\gamma$ and iNOS, because impairment of these responses during latency has been shown, in each case, to promote parasite growth and the reappearance of lesions ${ }^{74,104,105}$. IL-10 was shown to have a crucial role in chronicity by the inability of the parasite to establish a persistent infection after healing in IL-10-deficient C57BL/10 mice and by the sterile immunity that was achieved in wild-type mice treated during the chronic phase with anti-IL-10R antibody ${ }^{105}$. So, the persistence of $L$. major does not seem to be explained adequately by the SAFE-TARGET MODEL ${ }^{101}$, because regardless of the nature of the cells harbouring the parasites, the absence of IL-10 allowed these cells to be activated for effective killing or, perhaps, to become sensitive to apoptotic pathways, thereby releasing parasites for uptake and killing by other cells. The clinical findings that are most relevant to these data are those indicating that even in healed cases of visceral or localized cutaneous disease, IL-10 continues to be produced together with IFN- $\gamma^{106,107,108}$, which might explain the failure of these individuals to achieve sterile cure. Recently, the source of the IL-10 in C57BL/ 6 mice was found to be a population of $\mathrm{CD} 4^{+} \mathrm{CD} 25^{+} \mathrm{CD} 45 \mathrm{RB}^{\text {low }}$ immunoregulatory T cells ${ }^{109}$ (FIG. 6), which links the $\mathrm{CD} 4^{+} \mathrm{CD} 45 \mathrm{RB}^{\text {low }} \mathrm{T}$-cell subset that suppresses L. major immunity in BALB/c mice ${ }^{22}$ with the naturally occurring suppressor cells that prevent sterile cure in resistant mice. Importantly, the IL-10-deficient and anti-IL-10R antibody-treated mice that achieved sterile cure were no longer immune to reinfection ${ }^{109}$, which indicates that the maintenance of effector memory $\mathrm{T}$ cells requires antigen persistence. Similar findings have been published recently ${ }^{110}$, in which the transfer of immune cells from sub-clinical mice could protect naive $\mathrm{BALB} / \mathrm{c}$ mice against a pathogenic challenge and could completely clear the parasite, leaving the mice susceptible to a re-challenge infection.

\section{Implications for vaccine design}

The observations regarding the need for both $\mathrm{CD}^{+}$ and $\mathrm{CD} 8^{+} \mathrm{T}$ cells for acquired resistance, as well as the requirements for sustained IL-12 production and parasite persistence to maintain immunity, have important which L. major parasites might infect and replicate in without activating immune responses. 


\begin{tabular}{|c|c|c|c|c|}
\hline Antigen & Vaccine form & Challenge model & Result & References \\
\hline \multirow[t]{2}{*}{ gp63 } & \multirow{2}{*}{$\begin{array}{l}\text { rgp63 expressed in Salmonella } \\
\text { rgp63 expressed in BCG } \\
\text { gp63 synthetic peptide } \\
\text { + poloxamer adjuvant } \\
\text { gp63 DNA }\end{array}$} & $\begin{array}{l}\text { BALB/c } \times \text { C57BL/6 } \\
\text { BALB/c, CBA } \\
\text { BALB/c }\end{array}$ & $\begin{array}{l}\text { Partial protection } \\
\text { Partial protection } \\
\text { Protection }\end{array}$ & $\begin{array}{l}130 \\
131 \\
132\end{array}$ \\
\hline & & $\mathrm{BALB} / \mathrm{c}$ & Partial protection & 133 \\
\hline PSA2 & $\begin{array}{l}\text { rPSA2 with C. parvum } \\
\text { PSA2 DNA }\end{array}$ & $\begin{array}{l}\mathrm{C} 3 \mathrm{H}, \mathrm{BALB} / \mathrm{C} \\
\mathrm{C} 3 \mathrm{H}\end{array}$ & $\begin{array}{l}\text { Protection } \\
\text { Complete protection }\end{array}$ & $\begin{array}{l}134 \\
135\end{array}$ \\
\hline LACK & $\begin{array}{l}\text { rLACK + rlL-12 } \\
\text { LACK DNA }\end{array}$ & $\begin{array}{l}\text { BALB/c } \\
\text { BALB/c }\end{array}$ & $\begin{array}{l}\text { Protection } \\
\text { Long-lived protection }\end{array}$ & $\begin{array}{r}74,136 \\
114\end{array}$ \\
\hline TSA & $\begin{array}{l}\text { rTSA + rlL-12 } \\
\text { TSA DNA }\end{array}$ & $\begin{array}{l}\text { BALB/c } \\
\text { BALB/c }\end{array}$ & $\begin{array}{l}\text { Protection } \\
\text { Protection }\end{array}$ & $\begin{array}{l}137 \\
138\end{array}$ \\
\hline LmSTI1 & LmSTI1 DNA & $\mathrm{BALB} / \mathrm{c}$ & Protection & 138 \\
\hline $\begin{array}{l}\text { LmSTI1 } \\
+ \text { TSA } \\
+ \text { LACK }\end{array}$ & $\begin{array}{l}\text { LmSTI1 DNA + } \\
\text { TSA DNA + LACK } \\
\text { DNA }\end{array}$ & $\begin{array}{l}\text { C57BL/6 } \\
\text { (low-dose i.d.) }\end{array}$ & $\begin{array}{l}\text { Complete, long-lived } \\
\text { protection }\end{array}$ & 115 \\
\hline CP type I and II & CPI DNA + CPII DNA & $\mathrm{BALB} / \mathrm{c}$ & Long-lived protection & 139 \\
\hline Histone $\mathrm{H} 1$ & $\mathrm{rH} 1$ & $\mathrm{BALB} / \mathrm{c}$ & Partial protection & 140 \\
\hline SP15 & SP15 DNA & $\begin{array}{l}\text { BALB/c, C57BL/6 } \\
\text { (low-dose i.d. + SGH) }\end{array}$ & Protection & 120 \\
\hline Maxadilan $\$$ & rMaxadilan & CBA (high-dose s.c. + SGH) & Protection & 121 \\
\hline \multicolumn{5}{|c|}{$\begin{array}{l}\text { *All vaccinated mice were evaluated using high-dose, subcutaneous (s.c.) challenge 2-4 weeks after vaccination, unless indicated } \\
\text { otherwise. Partial protection refers to outcomes in which only a fraction of the vaccinated animals had reduced lesion scores or in which } \\
\text { BALB/c mice had a delayed, but still progressive, lesion development. Protection refers to moderated lesion scores in all vaccinated } \\
\text { mice. Complete protection refers to the absence of lesions in all mice. Long-lived protection refers to protection achieved in mice } \\
\text { challenged at least three months after vaccination. FFrom Phlebotomus papatasi saliva. SFrom Lutzomyia longipalpis saliva. BCG, } \\
\text { Mycobacterium bovis bacillus Calmette-Guerin; CP, cysteine proteinase; C. parvum, Cryptosporidium parvum; gp, glycoprotein; } \\
\text { i.d., intradermal; IL-12, interleukin-12; LACK, Leishmania homologue of receptors for activated C kinase; PSA2, promastigote surface } \\
\text { antigen 2; r, recombinant; SGH, salivary-gland homogenate; TSA, thiol-specific antioxidant. }\end{array}$} \\
\hline
\end{tabular}

implications with regard to vaccination strategies. The concern that non-living, protein-based vaccines will elicit poor $\mathrm{CD}^{+} \mathrm{T}$-cell responses and be less potent and durable than live vaccines has, to some extent, been substantiated in human trials. Live vaccination, or leishmanization as it is known - which involves the inoculation of virulent organisms in the arm to protect against the development of severe or multiple lesions, particularly on the face - provides virtually complete and life-long protection ${ }^{111}$. By contrast, a safe, non-living vaccine made up of whole-cell killed Leishmania inoculated with Mycobacterium bovis bacillus Calmette-Guerin (BCG) as an adjuvant failed to confer substantial protection to humans against cutaneous disease ${ }^{112,113}$. The underlying problems with this vaccine are indicated by recent results from the L. major mouse model; mice immunized with killed promastigotes or recombinant proteins plus IL-12 as an adjuvant had a high level of protection when challenged 2-4 weeks after vaccination, but they had already lost a substantial degree of protection when challenged after 12 weeks ${ }^{114,115}$. Immunity could be maintained by repeated administration of antigen or IL-12 (REF. 74), or by antigen and/or IL-12 delivered by plasmid DNA ${ }^{114,115}$. Immunization using plasmid DNA encoding single or multiple Leishmania antigens is a particularly effective approach to generate strong and long-lasting protection against $L$. major, owing to its ability to induce $\mathrm{CD} 4^{+}$and $\mathrm{CD} 8^{+} \mathrm{T}$-cell responses, its sustained delivery of antigen and its provision of a strong $\mathrm{T}_{\mathrm{H}} 1$-promoting adjuvant in the form of unmethylated $\mathrm{CpG}$ dinucleotide motifs ${ }^{116}$. TABLE 1 provides a summary of many of the defined, subunit vaccines - either recombinant protein- or DNAbased - that have shown some degree of efficacy in the L. major mouse model.

As more natural challenge models have revealed differences in the immune mechanisms that are required to control infection, it will be important to evaluate candidate vaccines using sandfly challenge. In addition to the inoculum size and site of challenge, sandfly-transmitted infections differ from those initiated by a needle in that infected sandflies also inoculate small amounts of saliva. Many studies have reported that the co-injection of parasites with salivary-gland homogenates of vector sandflies produces a substantial increase in lesion size and/or parasite burden that is due, in large part, to an upregulation of type- 2 responses by components in the salivarygland lysate ${ }^{117}$. Furthermore, pre-exposure of mice to sandfly saliva was found to neutralize the enhancing effects of saliva ${ }^{118}$ and to confer powerful protection against $L$. major infection transmitted by sandfly bite ${ }^{119}$. Protection was associated with a strong delayed-type hypersensitivity response, including the production of IFN- $\gamma$ and IL- 12 at the site of the bite, which indicates that in this inflammatory setting, infected macrophages might be activated for early killing of the parasites. These results have prompted the use of defined salivary antigens, delivered as either recombinant proteins or as plasmid DNA, to vaccinate mice against a challenge inoculation containing $L$. major plus sandfly saliva ${ }^{120,121}$. 


\section{Concluding comments}

The mouse L. major infection model remains a popular tool for immunologists to investigate the contribution of various factors - for example, cytokines, receptors or signalling molecules - to the development of a $\mathrm{T}_{H} 1$ or $\mathrm{T}_{\mathrm{H}} 2$ response in vivo. Although some surprises have emerged from these studies that challenge some basic tenets of the $T_{H} 1 / T_{H} 2$ model, important unifying themes can be discerned. L. major seems to initiate an early $\mathrm{T}_{\mathrm{H}} 2$ response that is redirected effectively in resistant mice by IL-12-dependent mechanisms. By contrast, in susceptible mice - either because of inherent instabilities in IL-12R expression and/or because the parasites disseminate to tissues that preferentially drive $\mathrm{T}_{\mathrm{H}} 2$ development - the $\mathrm{T}_{\mathrm{H}} 2$ response is maintained and dominates the clinical outcome. The ability of redundant deactivating cytokines, including IL-4, IL-13, IL-10 and TGF- $\beta$, to prevent effective killing of the parasite, even when $T_{H} 1$ responses are induced also, might explain why ablation of IL-4 or IL- $4 \mathrm{R}$ signalling in $\mathrm{BALB} / \mathrm{c}$ mice is, in some cases, insufficient to reverse susceptibility, particularly as IL-4 is not necessary to initiate $\mathrm{T}_{\mathrm{H}}$ 2-cell development in vivo. Whereas defects in $\mathrm{T}_{\mathrm{H}} 1$-response development might produce an imbalance in the number and activity of parasite-driven $\mathrm{T}_{\mathrm{H}} 2$ cells (possibly, regulatory T cells) in BALB/c mice, these same cells might operate in more dynamic equilibrium with $\mathrm{T}_{\mathrm{H}} 1$ effector cells in resistant mice, preventing the ability of the mice to achieve sterile cure, rather than the development or expression of resistance. Although there is an obvious advantage to the parasite to express epitopes (for example, LACK) that might exploit the activation of these $\mathrm{T}_{\mathrm{H}} 2$ cells, it seems equally probable that their function is of benefit to the host by moderating the tissue damage that is associated with powerful immune responses in the skin and by favouring parasite persistence so as to maintain life-long immunity to reinfection. The need for persistent antigen and sustained IL- 12 production to maintain the $\mathrm{CD} 4^{+}$and $\mathrm{CD} 8^{+}$ effector $\mathrm{T}$ cells that are responsible for acquired immunity will pose serious challenges to the development of a safe and effective non-living vaccine.
1. Sadick, M. D. et al. Cure of murine leishmaniasis with antiinterleukin-4 monoclonal antibody. Evidence for a T-celldependent, interferon-y-independent mechanism. J. Exp. Med 171, 115-127 (1990).

2. Chatelain, R., Varkila, K. \& Coffman, R. L. IL-4 induces $a T_{H}$ response in Leishmania major-infected mice. J. Immunol. 148, 1182-1187 (1992)

3. Kopf, M. et al. IL-4-deficient BALB/c mice resist infection with Leishmania major. J. Exp. Med. 184, 1127-1136 (1996).

4. Mohrs, M. et al. Differences between IL-4- and IL-4 receptor $\alpha$-deficient mice in chronic leishmaniasis reveal a protective role for IL-13 receptor signaling. J. Immunol. protective role for IL-13

$162,7302-7308$ (1999).
References $1-4$ provide strong evidence that the References $1-4$ provide strong evidence that the
production of IL-4 is essential for susceptibility to Leishmania major.

5. Launois, P. et al. IL- 4 rapidly produced by V $\beta 4$ V $\alpha 8$ CD 4 $T$ cells instructs $T_{H} 2$ development and susceptibility to Leishmania major in BALB/c mice. Immunity 6, 541-549 (1997).

6. Himmelich, H. et al. In BALB/c mice, IL-4 production during the initial phase of infection with Leishmania major is necessary and sufficient to instruct $T_{H} 2$-cell development resulting in progressive disease. J. Immunol. 164 4819-4825 (2000).

7. Julia, V., Rassoulzadegan, M. \& Glaichenhaus, N. Resistance to Leishmania major induced by tolerance to a single antigen. Science 274, 421-423 (1996). References 5-7 make the strong case that early IL-4 production by LACK-reactive cells controls susceptibility to $L$. major.

8. Malherbe, L. et al. Selective activation and expansion of high-affinity $\mathrm{CD} 4^{+} T$ cells in resistant mice upon infection with Leishmania major. Immunity 13, 771-782 (2000).

9. Shankar, A. H. \& Titus, R. G. T-cell and non-T-cel compartments can independently determine resistance to Leishmania major. J. Exp. Med. 181, 845-855 (1995).

10. Reiner, S. L., Wang, Z. E., Hatam, F., Scott, P. \& Locksley, R. M. $T_{4} 1$ and $T_{4} 2$ cell antigen receptors in experimental R. M. $T_{H} 1$ and $T_{H} 2$ cell antigen receptors in experim
leishmaniasis. Science $\mathbf{2 5 9}, 1457-1460$ (1993).

11. Julia, V. \& Glaichenhaus, N. CD4 ${ }^{+} T$ cells which react to the Leishmania major LACK antigen rapidly secrete interleukinand are detrimental to the host in resistant B10.D2 mice. Infect. Immun. 67, 3641-3644 (1999).

12. Stetson, D. B., Mohrs, M., Mattlet-Designe, V., Teyton, L. \& Locksley, R. M. Rapid expansion and IL-4 expression by Leishmania-specific naive helper T cells in vivo. Immunity $\mathbf{1 7}$ 191-200 (2002).

A convincing demonstration that early IL-4 production by LACK-reactive cells occurs in both susceptible and resistant mouse strains.

13. Morris, L., Troutt, A. B., Handman, E. \& Kelso, A. Changes in the precursor frequencies of IL-4 and IFN- $\gamma$-secreting $\mathrm{CD} 4^{+}$cells correlate with resolution of lesions in murine cutaneous leishmaniasis. J. Immunol 149, 2715-2721 (1992)

14. Belkaid, Y. et al. A natural model of Leishmania majo infection reveals a prolonged 'silent' phase of parasite amplification in the skin before the onset of lesion formation and immunity. J. Immunol. 165, 969-977 (2000).

15. Reiner, S. L., Zheng, S., Wang, Z. E., Stowring, L. \& Locksley, R. M. Leishmania promastigotes evade interleukin-12 (IL-12) induction by macrophages and stimulate a broad range of cytokines from $\mathrm{CD4}^{+} \mathrm{T}$ cells during initiation of infection. J. Exp. Med. 179, 447-456 (1994).

A thorough demonstration that $L$. major promastigotes behave as 'stealth' parasites in promastigotes behave as

16. Scott, P., Eaton, A., Gause, W. C., di Zhou, X. \& Hondowicz, B. Early IL-4 production does not predict susceptibility to Leishmania major. Exp. Parasitol. 84, 178-187 (1996). Early evidence that a rapid IL-4 response occurs in resistant, as well as susceptible, mice.

17. Heinzel, F. P., Rerko, R. M., Ahmed, F. \& Pearlman, E. Endogenous IL-12 is required for control of $\mathrm{T}_{\mathrm{H}} 2$ cytokine responses capable of exacerbating leishmaniasis in normally resistant mice. J. Immunol. 155, 730-739 (1995).

18. Hondowicz, B. D., Scharton-Kersten, T. M., Jones, D. E. \& Scott, P. Leishmania major-infected C3H mice treated with anti-IL-12 mAb develop but do not maintain a $T_{H} 2$ response. anti-LL-12 mAb develop but do not man

19. Erb, K. J., Blank, C. \& Moll, H. Susceptibility to Leishmania major in IL-4-transgenic mice is not correlated with the lack of a $\mathrm{T}_{H} 1$ immune response. Immunol. Cell. Biol. 74 239-244 (1996)

20. Leal, L. M., Moss, D. W., Kuhn, R., Muller, W. \& Liew, F. Y. Interleukin-4-transgenic mice of resistant background are susceptible to Leishmania major infection. Eur. J. Immuno. 23, 566-569 (1993).

21. Groux, H. et al. A transgenic model to analyze the immunoregulatory role of IL-10 secreted by antigenpresenting cells. J. Immunol. 162, 1723-1729 (1999).

22. Powrie, F., Correa-Oliveira, R., Mauze, S. \& Coffman, R. L Regulatory interactions between CD45RB high and Regulatory interactions between $\mathrm{CD} 45 \mathrm{RB}^{\text {high }}$ and
$\mathrm{CD} 45 \mathrm{RB}^{\mathrm{Bow}} \mathrm{CD} 4^{+} \mathrm{T}$ cells are important for the balance $\mathrm{CD} 45 \mathrm{RB}^{\text {low }} \mathrm{CD} 4+\mathrm{T}$ cells are important for the balance
between protective and pathogenic cell-mediated immunity. J. Exp. Med. 179, 589-600 (1994). A demonstration that $L$. major-specific $\mathrm{T}_{\mathrm{H}} \mathbf{1}$ effector cells can be recovered from infected $B A L B / c$ mice and that they are suppressed by $\mathrm{CD4} 4^{+} \mathrm{T}$ cells that are a subset of an immunoregulatory population that can suppress colitis also.

23. Bogdan, C., Rollinghoff, M. \& Diefenbach, A. Reactive oxygen and reactive nitrogen intermediates in innate and specific immunity. Curr. Opin. Immunol. 12, 64-76 (2000).

24. Heinzel, F. P., Schoenhaut, D. S., Rerko, R. M., Rosser, L. E. \& Gately, M. K. Recombinant interleukin-12 cures mice infected with Leishmania major. J. Exp. Med. 177, 1505-1509 (1993).
25. Sypek, J.P et al Resolution of cutaneous leishmaniasis: interleukin-12 initiates a protective Thelper type 1 immune response. J. Exp. Med. 177, 1797-1802 (1993). References 24 and 25 were the first to show the role of IL-12 in initiating a $T_{H} 1$ response and resistance to L. major.

26. Mattner, F. et al. Genetically resistant mice lacking interleukin-12 are susceptible to infection with Leishmania major and mount a polarized $\mathrm{T}_{\mathrm{H}} 2$ cell response. Eur. $\mathrm{J}$. Immunol. 26, 1553-1559 (1996).

27. Hondowicz, B. D., Park, A. Y., Elloso, M. M. \& Scott, P. Maintenance of IL-12-responsive $\mathrm{CD} 4^{+} \mathrm{T}$ cells during a $\mathrm{T}_{4} 2$ response in Leishmania major-infected mice. Eur. J. Immunol. 30, 2007-2014 (2000).

28. Himmelrich, H., Parra-Lopez, C., Tacchini-Cottier, F., Louis, J. A. \& Launois, P. The IL-4 rapidly produced in BALB/C mice after infection with Leishmania major down-regulates $\mathrm{IL}$-12 receptor $\beta 2$-chain expression on $\mathrm{CD} 4+\mathrm{T}$ cells resulting in a state of unresponsiveness to IL-12. J. Immunol. 161, 6156-6163 (1998).

29. Guler, M. L. et al. Genetic susceptibility to Leishmania: IL-12 responsiveness in $T_{H} 1$ cell development. Science $\mathbf{2 7 1}$ 984-987 (1996).

30. Nishikomori, R., Gurunathan, S., Nishikomori, K. \& Strober, W. $\mathrm{BALB} / \mathrm{c}$ mice bearing a transgenic IL-12 receptor- $\beta 2$ gene exhibit a nonhealing phenotype to Leishmania major infection despite intact IL-12 signaling. J. Immunol. 166 6776-6783 (2001).

31. Beil, W. J., Meinardus-Hager, G., Neugebauer, D. C. \& Sorg, C. Differences in the onset of the inflammatory response to cutaneous leishmaniasis in resistant and susceptible mice. J. Leukocyte Biol. 52, 135-142 (1992).

32. Tacchini-Cottier, F. et al. An immunomodulatory function for neutrophils during the induction of a CD4 $4^{+} \mathrm{T}_{H} 2$ response in $\mathrm{BALB} / \mathrm{c}$ mice infected with Leishmania major. J. Immunol. 165, 2628-2636 (2000).

33. Laskay, T., Diefenbach, A., Rollinghoff, M. \& Solbach, W. Early parasite containment is decisive for resistance to Leishmania major infection. Eur. J. Immunol. 25, 2220-2227 (1995). The first demonstration that $L$ major promastigotes The first demonstration that $L$. major promastigotes
disseminate rapidly to the viscera in BALB/c mice, but disseminate rapidly to

34. Yamashita, T. et al. CD4 $4^{+}$and/or $\gamma \delta^{+} T$ cells in the liver spontaneously produce IL-4 in vitro during the early phase of Leishmania major infection in susceptible BALB/c mice. Acta Trop. 73, 109-119 (1999).

35. Nabors, G. S., Nolan, T., Croop, W., Li, J. \& Farrell, J. P. The influence of the site of parasite inoculation on the development of $\mathrm{T}_{H} 1$ - and $\mathrm{T}_{\mathrm{H}} 2$-type immune responses in (BALB/C $\times$ C57BL/6) F1 mice infected with Leishmania major. Parasite Immunol. 17, 569-579 (1995).

36. Constant, S. L., Lee, K. S. \& Bottomly, K. Site of antigen delivery can influence T-cell priming: pulmonary environment promotes preferential T 2-type differentiation. Eur. $J$. Immunol. 30, 840-847 (2000). 
A clear demonstration that the tissue site of parasite delivery can influence the class of effector cell that is induced.

37. Khanna, A. et al. Effects of liver-derived dendritic-cell progenitors on $\mathrm{T}_{\mathrm{H}} 1$ - and $\mathrm{T}_{\mathrm{H}} 2$-like cytokine responses in vitro and in vivo. J. Immunol. 164, 1346-1354 (2000).

38. $\mathrm{Gu}, \mathrm{L}$. et al. Control of $\mathrm{T}_{\mathrm{H}} 2$ polarization by the chemokine monocyte chemoattractant protein-1. Nature $\mathbf{4 0 4}, 407-41$ (2000).

39. Saha, B., Chattopadhyay, S., Germond, R., Harlan, D. M. \& Perrin, P. J. CTLA4 (CD152) modulates the $T_{H}$-subset response and alters the course of experimental Leishmania major infection. Eur. J. Immunol. 28, 4213-4220 (1998).

40. Corry, D. B., Reiner, S. L., Linsley, P. S. \& Locksley, R. M. Differential effects of blockade of CD28-B7 on the development of $\mathrm{T}_{H} 1$ or $\mathrm{T}_{H} 2$ effector cells in experimental leishmaniasis. J. Immunol. 153, 4142-4148 (1994).

41. Brown, J. A., Titus, R. G., Nabavi, N. \& Glimcher, L. H. Blockade of CD86 ameliorates Leishmania major infection by down-regulating the $T_{H} 2$ response. J. Infect. Dis. 174 1303-1308 (1996)

42. Akiba, H. et al. Critical contribution of OX4O ligand to Thelper cell type 2 differentiation in experimental leishmaniasis. J. Exp. Med. 191, 375-380 (2000)

43. von Stebut, E. et al. Leishmania major-infected murine Langerhans cell-like dendritic cells from susceptible mice release IL-12 after infection and vaccinate against experimental cutaneous Leishmaniasis. Eur. J. Immunol 30, 3498-3506 (2000)

44. Bretscher, P. A., Wei, G., Menon, J. N. \& Bielefeldt-Ohmann, H Establishment of stable, cell-mediated immunity that makes 'susceptible' mice resistant to Leishmania major. Science 257, 539-542 (1992). Strong evidence that parasite dose can influence the effector class.

45. Howard, J. G., Nicklin, S., Hale, C. \& Liew, F. Y. Prophylactic immunization against experimental leishmaniasis I. Protection induced in mice genetically vulnerable to fatal Leishmania tropica infection. J. Immunol. 129, 2206-2212 (1982).

46. Aebischer, T., Morris, L. \& Handman, E. Intravenous injection of irradiated Leishmania major into susceptible BALB/C mice: immunization or protective tolerance. Int. Immunol. 6, 1535-1543 (1994)

47. Beebe, A. M., Mauze, S., Schork, N. J. \& Coffman, R. L. Serial backcross mapping of multiple loci associated with resistance to Leishmania major in mice. Immunity 6, 551-557 (1997).

48. Lipoldova, M. et al. Susceptibility to Leishmania major infection in mice: multiple loci and heterogeneity of infection in mice: multiple loci and heterogeneity
immunopathological phenotypes. Genes Immun immunopathological

49. Noben-Trauth, N., Paul, W. E. \& Sacks, D. L. IL-4- and IL-4-receptor-deficient BALB/c mice reveal differences in susceptibility to Leishmania major parasite substrains. J. Immunol. 162, 6132-6140 (1999).

50. Matthews, D. J. et al. IL-13 is a susceptibility factor for Leishmania major infection. J. Immunol. 164, 1458-1462 (2000)

51. Noben-Trauth, N., Kropf, P. \& Muller, I. Susceptibility to Leishmania major infection in interleukin-4-deficient mice. Science 271, 987-990 (1996).

\section{The first serious challenge to the established mode} regarding the role of IL-4 in susceptibility to $L$ major.

52. Kropf, P. et al. Expression of T 2 cytokines and the stable $\mathrm{T}_{\mathrm{H}} 2$ marker ST2L in the absence of IL-4 during Leishmania major infection. Eur. J. Immunol. 29, 3621-3628 (1999).

53. Li, J., Hunter, C. A. \& Farrell, J. P. Anti-TGF- $\beta$ treatmen promotes rapid healing of Leishmania major infection in mice by enhancing in vivo nitric oxide production. J. Immunol. 162, 974-979 (1999).

54. Gorelik, L., Constant, S. L. \& Flavell, R. A. Mechanism of transforming growth factor- $\beta$-induced inhibition of $T$ helper type I differentiation. J. Exp. Med. 195, 1499-1505 (2002).

55. Chatelain, R., Mauze, S. \& Coffman, R. L. Experimental Leishmania major infection in mice: role of IL-10. Parasite Leishmania major infection in mice.

56. Yamakami, $\mathrm{K}$ et al Administration of plasmids expressing interleukin- 4 and interleukin- 10 causes BALB/c mice to induce a T helper 2-type response, despite the expected Thelper 1-type response, with a low-dose infection of Leishmania major. Immunology 105, 515-523 (2002).

57. Kane, M. M. \& Mosser, D. M. The role of IL-10 in promoting disease progression in leishmaniasis. J. Immunol. 166 1141-1147 (2001).

A clear demonstration that IL-10 contributes to susceptibility to $L$. major in BALB/c mice.

58. Kropf, P. et al. Characterization of T-cell-mediated responses in nonhealing and healing Leishmania major infections in the in nonhealing and healing Leishmania major infections in the
absence of endogenous IL-4. J. Immunol. 159, 3434-3443 (1997).
59. Shevach, E. M. Certified professionals: $\mathrm{CD} 4^{+} \mathrm{CD} 25^{+}$ suppressor T cells. J. Exp. Med. 193, F41-F46 (2001).

60. Mohrs, M., Holscher, C. \& Brombacher, F. Interleukin-4 receptor $\alpha$-deficient BALB/c mice show an unimpaired Thelper 2 polarization in response to Leishmania majo infection. Infect. Immun. 68, 1773-1780 (2000).

61. Melby, P. C. et al. Increased expression of proinflammatory cytokines in chronic lesions of human cutaneous leishmaniasis. Infect. Immun. 62, 837-842 (1994).

62. Karp, C. L. et al. In vivo cytokine profiles in patients with kala-azar. Marked elevation of both interleukin-10 and interferon-ץ. J. Clin. Invest. 91, 1644-1648 (1993).

63. Gasim, S. et al. High levels of plasma IL-10 and expression of IL-10 by keratinocytes during visceral leishmaniasis predict subsequent development of post-kala-azar derma leishmaniasis. Clin. Exp. Immunol. 111, 64-69 (1998)

64. Wang, Z. E., Reiner, S. L., Zheng, S., Dalton, D. K. \& Locksley, R. M. CD4+ effector cells default to the $\mathrm{T}_{\mathrm{H}}$ pathway in interferon- $\gamma$-deficient mice infected with Leishmania major. J. Exp. Med. 179, 1367-1371 (1994).

65. Szabo, S. J. et al. Distinct effects of T-bet in $T_{H} 1$ lineage commitment and IFN- $\gamma$ production in CD4 and CD8 T cells. Science 295, 338-342 (2002).

66. Campbell, K. A. et al. CD40 ligand is required for protective cell-mediated immunity to Leishmania major. Immunity 4, 283-289 (1996)

67. Kamanaka, M. et al. Protective role of CD40 in Leishmania major infection at two distinct phases of cell-mediated immunity. Immunity 4. 275-281 (1996).

68. Swihart, K. et al. Mice from a genetically resistant background lacking the interferon- $\gamma$ receptor are susceptible to infection with Leishmania major but mount a polarized to infection with Leishmania major but mount a polarized 961-971 (1995).

69. Stamm, L. M., Satoskar, A. A., Ghosh, S. K., David, J. R. 8 Satoskar, A. R. STAT-4-mediated IL-12 signaling pathway is critical for the development of protective immunity in cutaneous leishmaniasis. Eur. J. Immunol. 29, 2524-2529 (1999).

70. Monteforte, G. M. et al. Genetically resistant mice lacking IL-18 gene develop $T_{H} 1$ response and control cutaneous Leishmania major infection. J. Immunol. 164, 5890-5893 (2000).

71. Wei, X. et al. Altered immune responses and susceptibility to Leishmania major and Staphylococcus aureus infection in IL-18-deficient mice. J. Immunol. 163, 2821-2828 (1999).

72. Yoshida, $H$. et al. WSX-1 is required for the initiation of $T_{H}$ responses and resistance to $L$. major infection. Immunity 15, 569-578 (2001).

73. Park, A. Y., Hondowicz, B. D. \& Scott, P. IL-12 is required to maintain a $T$ 1 response during Leishmania major infection. J. Immunol. 165, 896-902 (2000).

74. Stobie, L. et al. The role of antigen and IL-12 in sustaining T 1 memory cells in vivo: IL-12 is required to maintain memory/effector $T_{1} 1$ cells sufficient to mediate protection to an infectious parasite challenge. Proc. Natt Acad. Sci. USA 97, 8427-8432 (2000).

\section{References 73 and 74 show the requirement for} sustained IL-12 production to maintain $\mathrm{T}_{\mathrm{H}} 1$ effector cells.

75. Park, A. Y. \& Scott, P. IL-12: keeping cell-mediated immunity alive. Scand. J. Immunol. 53, 529-532 (2001).

76. Carrera, L. et al. Leishmania promastigotes selectively inhibit interleukin-12 induction in bone-marrow-derived macrophages from susceptible and resistant mice. J. Exp. Med. 183, 515-526 (1996).

77. Sartori, A., Oliveira, M. A., Scott, P. \& Trinchieri, G. Metacyclogenesis modulates the ability of Leishmania promastigotes to induce IL-12 production in human mononuclear cells. J. Immunol. 159, 2849-2857 (1997).

78. Blank, C., Fuchs, H., Rappersberger, K., Rollinghoff, M \& Moll, H. Parasitism of epidermal Langerhans cells in experimental cutaneous leishmaniasis with Leishmania major. J. Infect. Dis. 167, 418-425 (1993).

79. von Stebut, E., Belkaid, Y., Jakob, T., Sacks, D. L. \& Udey, M. C. Uptake of Leishmania major amastigotes results in activation and interleukin-12 release from murine skinderived dendritic cells: implications for the initiation of antiLeishmania immunity. J. Exp. Med. 188, 1547-1552 (1998).

80. Konecny, P. et al. Murine dendritic cells internalize Leishmania major promastigotes, produce IL-12 p40 and stimulate primary T-cell proliferation in vitro. Eur. J. Immunol. 29, 1803-1811 (1999).

81. Moll, H. \& Flohe, S. Dendritic cells induce immunity to cutaneous leishmaniasis in mice. Adv. Exp. Med. Biol. 417 541-545 (1997)

82. Moll, H., Fuchs, H., Blank, C. \& Rollinghoff, M. Langerhans cells transport Leishmania major from the infected skin to the draining lymph node for presentation to antigen-specific T cells. Eur. J. Immunol. 23, 1595-1601 (1993).
Part of an early series of papers from this group showing the role of dendritic cells in T-cell priming

83. Sato, N. et al. CC-chemokine receptor (CCR)2 is required for Langerhans cell migration and localization of Thelper cel type $1\left(T_{H} 1\right)$-inducing dendritic cells. Absence of CCR2 shifts the Leishmania major-resistant phenotype to a susceptible state dominated by $T_{H} 2$ cytokines, B-cell outgrowth and sustained neutrophilic inflammation. $J$ Exp. Med 192 205-218 (2000).

84. Scharton, T. M. \& Scott, P. Natural killer cells are a source of interferon- $\gamma$ that drives differentiation of $C D 4^{+} T$-cell subsets and induces early resistance to Leishmania major in mice. J. Exp. Med. 178, 567-577 (1993)

85. Wakil, A. E., Wang, Z. E., Ryan, J. C., Fowell, D. J. \& Locksley, R. M. Interferon- $\gamma$ derived from CD4+ $4^{+}$cells is sufficient to mediate Thelper cell type 1 development. J. Exp. Med. 188, 1651-1656 (1998).

86. Satoskar, A. R. et al. Mice lacking NK cells develop an efficient $T_{H} 1$ response and control cutaneous Leishmania major infection. J. Immunol. 162, 6747-6754 (1999).

87. Bogdan, C., Moll, H., Solbach, W. \& Rollinghoff, M. Tumor necrosis factor- $\alpha$ in combination with interferon- $\gamma$, but not with interleukin-4, activates murine macrophages for elimination of Leishmania major amastigotes. Eur. J. Immunol. 20, 1131-1135 (1990).

88. Wei, X. Q. et al. Altered immune responses in mice lacking inducible nitric oxide synthase. Nature 375, 408-411 (1995)

89. Wilhelm, P. et al. Rapidly fatal leishmaniasis in resistant C57BL/6 mice lacking TNF. J. Immunol. 166, 4012-4019 (2001).

90. Nashleanas, M., Kanaly, S. \& Scott, P. Control of Leishmania major infection in mice lacking TNF receptors. J. Immunol. 160, 5506-5513 (1998)

91. Huang, F. P. et al. Mice defective in Fas are highly susceptible to Leishmania major infection despite elevated $\mathrm{IL}-12$ synthesis, strong $T_{H} 1$ responses and enhanced nitric oxide production. J. Immunol. 160, 4143-4147 (1998).

92. Conceicao-Silva, F., Hahne, M., Schroter, M., Louis, J. \& Tschopp, J. The resolution of lesions induced by Leishmania major in mice requires a functional Fas (APO-1, CD95) pathway of cytotoxicity. Eur. J. Immunol. 28, 237-245 (1998)

93. Chakkalath, H. R. et al. Class II major histocompatibility complex-deficient mice initially control an infection with Leishmania major but succumb to the disease. J. Infect. Dis. 171, 1302-1308 (1995).

94. Erb, K., Blank, C., Ritter, U., Bluethmann, H. \& Moll, H. Leishmania major infection in major histocompatibility complex class II-deficient mice: $\mathrm{CD}^{+} \mathrm{T}$ cells do not mediate a protective immune response. Immunobiology $\mathbf{1 9 5}$, 243-260 (1996).

95. Muller, I. Role of T-cell subsets during the recall of immunologic memory to Leishmania major. Eur. J. Immunol. 22, 3063-3069 (1992).

96. Huber, M., Timms, E., Mak, T. W., Rollinghoff, M. \& Lohoff, M. Effective and long-lasting immunity against the parasite Leishmania major in CD8-deficient mice. Infect. Immun. 66, 3968-3970 (1998).

97. Titus, R. G. et al. Involvement of specific Lyt-2+ $T$ cells in the immunological control of experimentally induced murine cutaneous leishmaniasis. Eur. J. Immunol. 17, 1429-1433 (1987).

98. Belkaid, Y. et al. $C D 8^{+} T$ cells are required for primary immunity in C57BL/6 mice following low-dose, intradermal challenge with Leishmania major. J. Immunol. 168, 3992-4000 (2002).

\section{2-4000 (2002). \\ A demonstration that $\mathrm{CD}^{+} \mathbf{T}$ cells are essential for}

primary immunity in resistant mice.

99. Da-Cruz, A. M., Conceicao-Silva, F., Bertho, A. L. \& Coutinho, S. G. Leishmania-reactive CD4+ and CD8 $8^{+}$T cells associated with cure of human cutaneous leishmaniasis. Infect. Immun. 62, 2614-2618 (1994).

100. Gaafar, A. et al. Characterization of the local and systemic immune responses in patients with cutaneous leishmaniasis due to Leishmania major. Clin. Immunol. 91, 314-320 (1999).

101. Bogdan, C. et al. Fibroblasts as host cells in latent leishmaniasis. J. Exp. Med. 191, 2121-2130 (2000).

102. Moll, H., Flohe, S. \& Blank, C. Dendritic cells seclude Leishmania parasites that persist in cured mice - a role in the maintenance of T-cell memory? Adv. Exp. Med. Biol. 378, 507-509 (1995).

103. Aebischer, T., Moody, S. F. \& Handman, E. Persistence of virulent Leishmania major in murine cutaneous leishmaniasis: a possible hazard for the host. Infect. Immun. 61, 220-226 (1993).

One of the first demonstrations that $L$. major persists after healing in resistant mice.

104. Stenger, S., Donhauser, N., Thuring, H., Rollinghoff, M. \& Bogdan, C. Reactivation of latent leishmaniasis by inhibition of inducible nitric oxide synthase. J. Exp. Med. 183, 1501-1514 (1996). 
105. Belkaid, Y. et al. The role of interleukin (IL)-10 in the persistence of Leishmania major in the skin after healing and the therapeutic potential of anti-IL-10 receptor antibody for sterile cure. J. Exp. Med. 194, 1497-1506 (2001). A demonstration that IL-10 is required for $L$. major persistence in healed mice.

106. Louzir, H. et al. Immunologic determinants of disease evolution in localized cutaneous leishmaniasis due to Leishmania major. J. Infect. Dis. 177, 1687-1695 (1998).

107. Bosque, F., Saravia, N. G., Valderrama, L. \& Milon, G. Distinct innate and acquired immune responses to Leishmania in putative susceptible and resistant human populations endemically exposed to $L$. Niannia) panamensis infection. Scand. J. Immunol. 51, 533-541 (2000).

108. Kemp, K. et al. Leishmania-specific T cells expressing interferon- $\gamma$ (IFN- $\gamma$ ) and IL-10 upon activation are expanded in individuals cured of visceral leishmaniasis. Clin. Exp. Immunol. 116, 500-504 (1999).

109. Belkaid, Y., Piccirillo, C. A., Mendez, S., Shevach, E. \& Sacks, D. CD4+CD25+ immunoregulatory T lymphocytes control Leishmania major persistence and the development of concomitant immunity. Nature (in the press).

110. Uzonna, J. E., Wei, G., Yurkowski, D. \& Bretscher, P. Immune elimination of Leishmania major in mice: implications for immune memory, vaccination and reactivation disease. J. Immunol. 167, 6967-6974 (2001). The first indication that sterile cure results in the loss of immunity to re-infection.

111. Modabber, F. Experiences with vaccines against cutaneous leishmaniasis: of men and mice. Parasitology 98, S49-S60 (1989).

112. Sharifi, I. et al. Randomised vaccine trial of single dose of killed Leishmania major plus BCG against anthroponotic cutaneous leishmaniasis in Bam, Iran. Lancet 351 cutaneous leishman

113. Momeni, A. Z. et al. A randomised, double-blind, controlled trial of a killed $L$. major vaccine plus BCG against zoonotic cutaneous leishmaniasis in Iran. Vaccine 17, 466-472 (1999).

114. Gurunathan, S., Prussin, C., Sacks, D. L. \& Seder, R. A. Vaccine requirements for sustained cellular immunity to an intracellular parasitic infection. Nature Med. 4, 1409-1415 (1998).

A demonstration that long-lasting vaccine-induced protection requires persistent antigen and IL-12.

115. Mendez, S. et al. The potency and durability of DNA- and protein-based vaccines against Leishmania major evaluated using low-dose, intradermal challenge. J. Immunol. 166 5122-5128 (2001).

116. Seder, R. A. \& Hill, A. V. Vaccines against intracellular infections requiring cellular immunity. Nature 406, 793-798 (2000).

117. Gillespie, R. D., Mbow, M. L. \& Titus, R. G. The immunomodulatory factors of bloodfeeding arthropod saliva. Parasite Immunol. 22, 319-331 (2000).

118. Belkaid, Y. et al. Development of a natural model of cutaneous leishmaniasis: powerful effects of vector saliva and saliva preexposure on the long-term outcome of
Leishmania major infection in the mouse ear dermis. J. Exp. Med. 188, 1941-1953 (1998)

119. Kamhawi, S., Belkaid, Y., Modi, G., Rowton, E. \& Sacks, D. Protection against cutaneous leishmaniasis resulting from bites of uninfected sand flies. Science 290, 1351-1354 (2000).

A demonstration that the immune response to sandfly saliva can potentiate the host response to $L$. major infection transmitted by sandfly bite.

120. Valenzuela, J. G. et al. Toward a defined anti-Leishmania vaccine targeting vector antigens: characterization of a vaccine targeting vector antigens: characterization of a
protective salivary protein. J. Exp. Med. 194, 331-342 protective
(2001).

121. Morris, R. V., Shoemaker, C. B., David, J. R., Lanzaro, G. C. \& Titus, R. G. Sandfly maxadilan exacerbates infection with Leishmania major and vaccinating against it protects agains L. major infection. J. Immunol. 167, 5226-5230 (2001).

122. Sacks, D. L., Hieny, S. \& Sher, A. Identification of cell-surface carbohydrate and antigenic changes between noninfective and infective developmental stages of Leishmania major promastigotes. J. Immunol. 135, 564-569 (1985).

123. Kellina, O. I. Differences in the sensitivity of inbred mice of different lines to Leishmania tropica major. Med. Parazitol. different lines to Leishmania
(Mosk.) 42, 279-285 (1973).

124. Nasseri, M. \& Modabber, F. Z. Generalized infection and lack of delayed hypersensitivity in BALB/c mice infected with Leishmania tropica major. Infect. Immun. 26, 611-614 (1979).

125. Howard, J. G., Hale, C. \& Liew, F. Y. Immunological regulation of experimental cutaneous leishmaniasis. III. Nature and significance of specific suppression of cellmediated immunity in mice highly susceptible to Leishmania tropica. J. Exp. Med. 152, 594-607 (1980).

126. Mosmann, T. R., Cherwinski, H., Bond, M. W., Giedlin, M. A. \& Coffman, R. L. Two types of murine helper T-cell clones. I. Definition according to profiles of Iymphokine activities and Definition according to profiles of lymphokine activities and

127. Scott, P., Natovitz, P., Coffman, R. L., Pearce, E. \& Sher, A. Immunoregulation of cutaneous leishmaniasis. T-cell lines that transfer protective immunity or exacerbation belong to different T-helper subsets and respond to distinct parasite antigens. J. Exp. Med. 168, 1675-1684 (1988).

128. Heinzel, F. P., Sadick, M. D., Holaday, B. J., Coffman, R. L. \& Locksley, R. M. Reciprocal expression of interferon- $\gamma$ or interleukin-4 during the resolution or progression of murine leishmaniasis. Evidence for expansion of distinct helper T-ishmaniasis. Evidence for expansion of distinct

129. Mock, B., Blackwell, J., Hilgers, J., Potter, M. \& Nacy, C. Genetic control of Leishmania major infection in congenic, recombinant inbred and F2 populations of mice. Eur. J. Immunogenet. 20, 335-348 (1993).

130. Yang, D. M. et al. Oral Salmonella typhimurium (AroA-) vaccine expressing a major leishmanial surface protein (gp63) preferentially induces Thelper 1 cells and protective immunity against leishmaniasis. J. Immunol. 145, 2281-2285 (1990).

131. Connell, N. D., Medina-Acosta, E., McMaster, W. R., Bloom, B. R. \& Russell, D. G. Effective immunization against cutaneous leishmaniasis with recombinant bacille Calmette-
Guerin expressing the Leishmania surface proteinase gp63 Proc. Natl Acad. Sci. USA 90, 11473-11477 (1993).

132. Spitzer, N., Jardim, A., Lippert, D. \& Olafson, R. W. Longterm protection of mice against Leishmania major with a synthetic peptide vaccine. Vaccine 17, 1298-1300 (1999).

133. Xu, D. \& Liew, F. Y. Protection against leishmaniasis by injection of DNA encoding a major surface glycoprotein

134. Handman, E., Symons, F. M., Baldwin, T. M., Curtis, J. M. \& Scheerlinck, J. P. Protective vaccination with promastigote surface antigen 2 from Leishmania major is mediated by a surface antigen 2 from Leishmania major is media 4261-4267 (1995).

135. Sjolander, A., Baldwin, T. M., Curtis, J. M. \& Handman, E. Induction of a $T_{H} 1$ immune response and simultaneous lack of activation of $\mathrm{T}_{\mathrm{H}} 2$ response are required for generation of immunity to leishmaniasis. J. Immunol. 160, 3949-3957 (1998).

136. Mougneau, E. et al. Expression cloning of a protective Leishmania antigen. Science 268, 563-566 (1995).

137. Webb, J. R. et al. Human and murine immune responses to a novel Leishmania major recombinant protein encoded by members of a multicopy gene family. Infect. Immun. 66, members of a multic

138. Campos-Neto, A. et al. Vaccination with plasmid DNA encoding TSALLMST11 leishmanial fusion proteins confers protection against Leishmania major infection in susceptible BALB/c mice. Infect. Immun. 70, 2828-2836 (2002).

139. Rafati, S., Salmanian, A. H., Taheri, T., Vafa, M. \& Fasel, N A protective cocktail vaccine against murine cutaneous leishmaniasis with DNA encoding cysteine proteinases of Leishmania major. Vaccine 19, 3369-3375 (2001).

140. Solioz, N. et al. The protective capacities of histone H against experimental murine cutaneous leishmaniasis. Vaccine 18, 850-859 (1999).

Acknowledgement

We thank A. Sher and D. Jankovic for critical review of the manuscript.

\section{(4) Online links}

\section{DATABASES}

The following terms in this article are linked online to: LocusLink: http://www.ncbi.nlm.nih.gov/LocusLink/ $\beta 2$-microglobulin | B7 | Bcl-6 | CCR2 | CD8 | CD28 | CD40 | CD40L | C-MAF | CTLA4 | Fas | FasL | FOG1 | GATA3 | IFN- $\gamma$ |

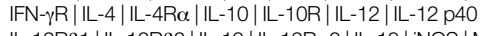
IL-12Rß1 | IL-12R $\beta 2$ | IL-13 | IL-13R $\alpha 2$ | IL-18 | iNOS | MCP1 | NFAT-c | OX40 | OX4OL | ROG | STAT1 | STAT4 | STAT6 | T-bet TGF- $\beta$ | TGF- $\beta$ receptor type II | TNF | TNFR1 | TNFR2 | WSX1 Swiss-Prot: http://ca.expasy.org/sprot/sprot-top.html

GFP

\section{FURTHER INFORMATION}

Mouse Genome Informatics: http://www.informatics.jax.org/ Access to this interactive links box is free online. 